\title{
Pacific Decadal Oscillation and recent oxygen decline in the eastern tropical Pacific Ocean
}

\author{
Olaf Duteil, Andreas Oschlies, and Claus W. Böning \\ GEOMAR - Helmholtz Centre for Ocean Research Kiel, Düsternbrooker Weg. 20, 24103 Kiel, Germany \\ Correspondence: Olaf Duteil (oduteil@geomar.de)
}

Received: 10 January 2018 - Discussion started: 19 January 2018

Revised: 8 October 2018 - Accepted: 10 October 2018 - Published: 29 November 2018

\begin{abstract}
The impact of the positive and negative phases of the Pacific Decadal Oscillation (PDO) on the extension of the poorly oxygenated regions of the eastern Pacific Ocean was assessed using a coupled ocean circulation-biogeochemical model. We show that during a "typical" PDO-positive phase the volume of the suboxic regions expands by $7 \%$ over 50 years due to a slowdown of the large-scale circulation related to the decrease in the intensity of the trade winds. Changes in oxygen levels are mostly controlled by advective processes between $10^{\circ} \mathrm{N}$ and $10^{\circ} \mathrm{S}$, whereas diffusive processes are dominant poleward of $10^{\circ}$ : in a "typical" PDO-positive phase the sluggish equatorial current system provides less oxygen to the eastern equatorial part of the basin while the oxygen transport by diffusive processes significantly decreases south of $10^{\circ} \mathrm{S}$. The suboxic region located north of $10^{\circ} \mathrm{N}$ displays less sensitivity to the phase of the PDO as the local upwelling-related processes play a dominant role compared to the large-scale circulation in setting the oxygen concentration. Our study suggests that the prevailing PDOpositive conditions since 1975 may explain a significant part of the current deoxygenation occurring in the eastern Pacific Ocean.
\end{abstract}

\section{Introduction}

Oxygen is one of the most important chemical elements in the ocean, as marine organisms ranging from microorganisms to vertebrates use it for respiration. Its concentration is regulated by both circulation and biogeochemical processes. In general, high-latitude regions are characterized by high oxygen concentrations, whereas subsurface tropical regions are poorly oxygenated. Particularly in the eastern parts of the tropical oceans, the large export of organic material out of productive surface layers combined with sluggish circulation depletes oxygen levels at depth, resulting in the formation of large suboxic regions where the oxygen concentration falls below $20 \mathrm{mmol} \mathrm{m}^{-3}$ (Karstensen et al., 2008). The overall contrast between high latitudes and tropical shadow zones is generally well reproduced by ocean models (Bopp et al., 2013; Cocco et al., 2013; Cabré et al., 2015; Shigemitsu et al., 2017).

The temporal variability of oxygen concentrations in the ocean interior is, nevertheless, still poorly understood; this is particularly true for the eastern tropical Pacific Ocean, where oxygen concentrations are among the lowest in the world (Karstensen et al., 2008). A strong decrease in oxygen concentrations in these regions has been inferred from observations ranging from the 1960s to the 2000s (Stramma et al., 2008, 2012; Schmidtko et al., 2017). This deoxygenation is not correctly reproduced by current ocean models (Oschlies et al., 2017). It is not clear whether the changes in oxygen concentration are due to anthropogenic changes (Matear et al., 2003; Long et al., 2016; Ito et al., 2017), or are related to natural low-frequency climate oscillations such as the Pacific Decadal Oscillation (PDO) (Deutsch et al., 2014), which is a robust and recurring pattern of ocean atmosphere climate variability centered over the midlatitude north Pacific basin (Mantua et al., 1997).

The stronger trade winds that occur during a negative phase of the PDO cause a shoaling of the eastern thermocline of the tropical and subtropical Pacific Ocean (Miller et al., 1994) (see the Supplement Fig. S1 for an overview of the mechanisms controlling the oxygen levels in the eastern tropical Pacific Ocean). Deutsch et al. $(2011,2014)$ showed that the depth of the thermocline regulates the oxygen lev- 
els in the northeastern subtropical Pacific Ocean. In these regions, a shallower thermocline fosters low oxygen concentrations in the intermediate ocean as a larger amount of organic material is respired below the mixed layer (Deutsch et al., 2011). Simultaneously, in the tropical regions the zonal volume transport by the equatorial current system increases during a negative PDO event as does the meridional transport by the subtropical cells (STCs) (Hong et al., 2014), which connect the subtropics to the tropics (McCreary and Lu, 1994). The variability of the strength of the STCs forces the variability of the oxygen transport in the upper thermocline of the equatorial Pacific Ocean (Duteil et al., 2014a). Therefore, competition takes place between the increased oxygen transport and the increased respiration as primary production is enhanced by the increased nutrient supply. Finally, stronger trade winds also increase the subduction volume of the North Pacific Eastern Subtropical Mode Water (Qu et al., 2009) and the South Pacific Eastern Subtropical Mode Water (Luo et al., 2011). A subtropical increase in productivity related to an increase in the trade winds causes a negative oxygen anomaly in these mode waters, which is transported equatorward and leads to a delayed oxygen decrease in tropical regions as shown by Ridder and England (2014) in an Earth system model of intermediate complexity.

All of these studies highlight the potential effect of the PDO on oxygen concentrations and show that the processes at play are diverse and strongly region dependent. However, we still do not have a clear picture of the impact of the PDO on the suboxic regions and on the oxygen levels of the eastern Pacific Ocean. Indeed, the studies cited above focus either specifically on the suboxic regions of the northeastern Pacific region (Deutsch et al., 2011, 2014) or on the upper thermocline of the tropical Pacific Ocean (Duteil et al., 2014a). A caveat of the model used by Ridder and England (2014) is that the equatorial undercurrent (EUC) is poorly represented, as is the case for most coarse-resolution (lower than $0.5^{\circ}$ at the equator) models (Karnauskas et al., 2012). The EUC indeed ventilates the suboxic regions, as shown by Cabre et al. (2015) and Shigemitsu et al. (2017) in a range of models as part of the Coupled Model Intercomparison Project 5 (CMIP5).

A precise understanding of the role of the PDO in setting oxygen levels is difficult in "traditional" 50-year hindcasts experiments (Deutsch et al., 2011; Ito and Deutsch, 2013; Duteil et al., 2014a) due to the superposition of a long-term climate trend and higher-frequency climate oscillations such as the El Niño-Southern Oscillation (ENSO) (Ito and Deutsch, 2013, 2016; Eddebbar et al., 2017). Ito and Deutsch (2013) showed that the temporal spectrum of oxygen concentrations in the northeastern tropical Pacific Ocean is characterized by a strong decadal variance which may partly arise from the "reddening" of the variability spectrum of the physical and biological drivers (Ito and Deutsch, 2010), suggesting, e.g., a contribution of ENSO to the decadal oxygen variability, in addition to the PDO.
Rather than performing a "hindcast" experiment, in this study we specifically isolate and assess the role of the phase of the PDO on the oxygen levels in the tropical eastern Pacific Ocean by forcing a coupled circulation-biogeochemical model using "typical" conditions characteristic of the negative and positive PDO phases. These idealized atmospheric forcings are derived from monthly averages of realistic winds and heat fluxes from the 1948-2007 COREv2 dataset (Large and Yeager, 2009). Our aim is to understand whether and by which processes (oxygen advection, diffusion, respiration) the PDO may be responsible for the observed oxygen decline in the suboxic regions of the tropical eastern Pacific Ocean.

This paper is organized as follows. Section 2 describes the construction of the "typical" PDO forcings and the configuration of the experiments that we perform. In Sect. 3, we assess the basin-scale circulation of our experiments. In Sect. 4, we present the difference in oxygen levels between a "typical" positive and a "typical" negative PDO phase. The mechanisms regulating the oxygen levels are described in Sect. 5. Temporal aspects are discussed in Sect. 6. In Sect. 7 we discuss the changes in the upwelling systems and the impact on suboxia. We then summarize our results in Sect. 8.

\section{Forcings and experiments}

The NEMO ocean model version v3.6 (Madec, 2008) was used in the standard ORCA2 configuration. This configuration has been widely used in previous studies and constitutes the ocean component of the ISPL-CM5A model, which is part of the Coupled Model Intercomparison Project (CMIP5) effort (Dufresnes et al., 2013). Its zonal resolution is 2 degrees. The mean meridional resolution is 2 degrees outside the tropics and increases to 0.5 degrees close to the Equator. The resolution of ORCA2 is sufficient to realistically reproduce the EUC (Cravatte et al., 2007) and the subtropicaltropical connectivity (Luebbecke et al., 2008). The circulation model has been coupled to a six-compartment (nutrient, phytoplankton, zooplankton, particulates and dissolved detritus, oxygen) biogeochemical model. This model is described in detail by Kriest et al. (2010). It was adapted to the NEMO framework by Duteil et al. (2014a, b).

We constructed three atmospheric forcing datasets derived from the interannual 1948-2007 COREv2, $6 \mathrm{~h}$ temporal resolution, forcing dataset (Large and Yeager, 2009):

- MEAN: (1) a low-pass filter was applied to remove the frequencies with a period shorter than 1 month. (2) The long term trend 1948-2007 (Yang et al., 2016) was removed. (3) The corresponding time steps of the individual annual forcings for the 1948-2007 period were averaged to reconstruct a climatological annually cycling forcing set. The difference between MEAN and the COREv2 "normal year" is the absence of highfrequency variability $(<1$ month $)$ and the removal of 
the long-term trend implicitly contained in the "normal year".

- PDO_PLUS (PDO_MINUS): steps (1) and (2) are similar to the first two steps mentioned above. In PDO_PLUS (PDO_MINUS), the corresponding time step of the years characterized by a positive (negative) PDO phase (Fig. 1a) were averaged, leading to the reconstruction of a 1 year, $6 \mathrm{~h}$ temporal resolution, climatological forcing "typical" of a PDO-positive (negative) phase.

In PDO_PLUS the zonal wind speed decreases by about 0.2 to $0.5 \mathrm{~ms}^{-1}$ compared to MEAN in the mid-equatorial Pacific Ocean, where the winds are strongest (at least $8 \mathrm{~ms}^{-1}$ ) (Fig. 1b). It increases close to the eastern coast by up to $0.3 \mathrm{~ms}^{-1}$, where the winds are weaker $\left(2\right.$ to $\left.8 \mathrm{~ms}^{-1}\right)$. A similar pattern was described by both Merrifield et al. (2012) and Zhou et al. (2017). The meridional wind speed decreases by about $0.2 \mathrm{~ms}^{-1}$ (Fig. 1c). The $10 \mathrm{~m}$ air temperature increases by 0.1 to $0.3^{\circ} \mathrm{C}$ in the eastern Pacific Ocean and decreases in the gyres (Fig. 1d). PDO_MINUS presents the opposite pattern.

We spun up the model over 1000 years using the MEAN forcing dataset. We subsequently performed two experiments using the PDO_PLUS and PDO_MINUS forcing datasets, respectively, which we integrated for a period of 50 years: this integration period corresponds to the typical oscillation period of the PDO over the past 200 years (Mc Donald and Case, 2005).

\section{Basin-scale circulation}

\subsection{Gyres}

The subtropical gyres (STG) slow down and extend equatorward in PDO_PLUS, constraining the tropical gyres (TG) (Fig. 1e). The slowdown reaches up to $5 \mathrm{~Sv}$ (or 5\%-10\%). These results are consistent with those from Messie and Chavez (2011), who analyzed the variability of the Extended Reconstruction Sea Surface Temperature (1910-2010) product (Smith et al., 2008) and showed that the intensity of the northern and southern Pacific subtropical gyres decreases during a positive PDO event (their Fig. 10). The thermocline depth shoals in PDO_PLUS in the STG and deepens in the eastern tropical part of the basin, correlated with a rise in sea level (Fig. 1f). The large signal observed at $10^{\circ} \mathrm{N}$ is related to the extension of the STG. The passive adjustment time of the ocean (without considering ocean-atmosphere feedbacks) is quick (a few years), which is coherent with previous studies (Zhang and Delworth, 2015; Deser et al., 1999; Hong et al., 2014).

\subsection{Meridional overturning}

The shallow meridional overturning is characterized by the presence of the STCs (Fig. 1g). These cells are shallow (upper $500 \mathrm{~m}$ ) structures connecting the subtropical and tropical regions (McCreary and Lu, 1994) and respond to a change in wind stress by baroclinic adjustment (Hong et al., 2014). The strength of the STCs (and therefore of the whole tropical current system, including the equatorial upwelling and the equatorial undercurrent) decreases by up to $5 \mathrm{~Sv}(10 \%)$ in PDO_PLUS compared to PDO_MINUS. The order of magnitude of the strength of the STCs in the PDO_PLUS and PDO_MINUS experiments are in line with other modeling studies (Lohman and Latif, 2005; Luebbecke et al., 2008; Hong et al., 2014) and with the observational study by McPhaden and Zhang (2002), which showed that the equatorial upwelling decreased by $10 \%$ from $1970-77$ (47 Sv) to 1980-89 (42 Sv) related to a shift of the phase of the PDO.

\section{Oxygen concentration}

\subsection{Comparison with the World Ocean Atlas}

At the end of the spin-up, the model reproduces the largescale features of the observed World Ocean Atlas (WOA) (Garcia et al., 2010) oxygen concentration field (Fig. 2a). The thickness of the SUB20 regions, defined as the regions where oxygen concentrations are lower than $20 \mathrm{mmol} \mathrm{m}^{-3}$ at the end of the spin-up, reaches more than $700 \mathrm{~m}$ north of the Equator both in the WOA (Fig. 2b) and in the model (Fig. 2c). "Typical" biases (Bopp et al., 2013; Cabre et al., 2015) are present in our model. In particular, (1) the OMZ region does not extend far enough westward, in particular north of the Equator, and (2) oxygen concentrations at the Equator are too low, maybe due to a poor representation of the intermediate current system, located below the EUC, in relatively coarse-resolution models (Marin et al., 2010; Getzlaff and Dietze, 2013). Nevertheless, the thickness of the suboxic regions is lower in the equatorial region compared to the tropics, as shown in Fig. 2c.

\subsection{Perturbation by the PDO}

After 50 years of integration time, the oxygen concentration (average 100-700 m) is lower in the eastern part of the basin in PDO_PLUS compared with PDO_MINUS (Fig. 2d). This decrease reaches up to $100 \%$ in regions where the oxygen is very low (below $5 \mathrm{mmol} \mathrm{m}^{-3}$ ) and about $5 \%-10 \%$ in regions where the oxygen concentration is lower than approximately $20 \mathrm{mmol} \mathrm{m}^{-3}$ (Fig. 2e). The volume of the SUB20 regions is $7 \%$ larger in PDO_PLUS and the thickness of the suboxic layer increases by up to $100 \mathrm{~m}$ close to the coast between $10^{\circ} \mathrm{N}$ and $10^{\circ} \mathrm{S}$ and at the outer boundary of the SUB20 regions (Fig. 2f; note that the "stepwise shape" of the anomaly is due to the discretization of the vertical grid of the ocean 
(a)
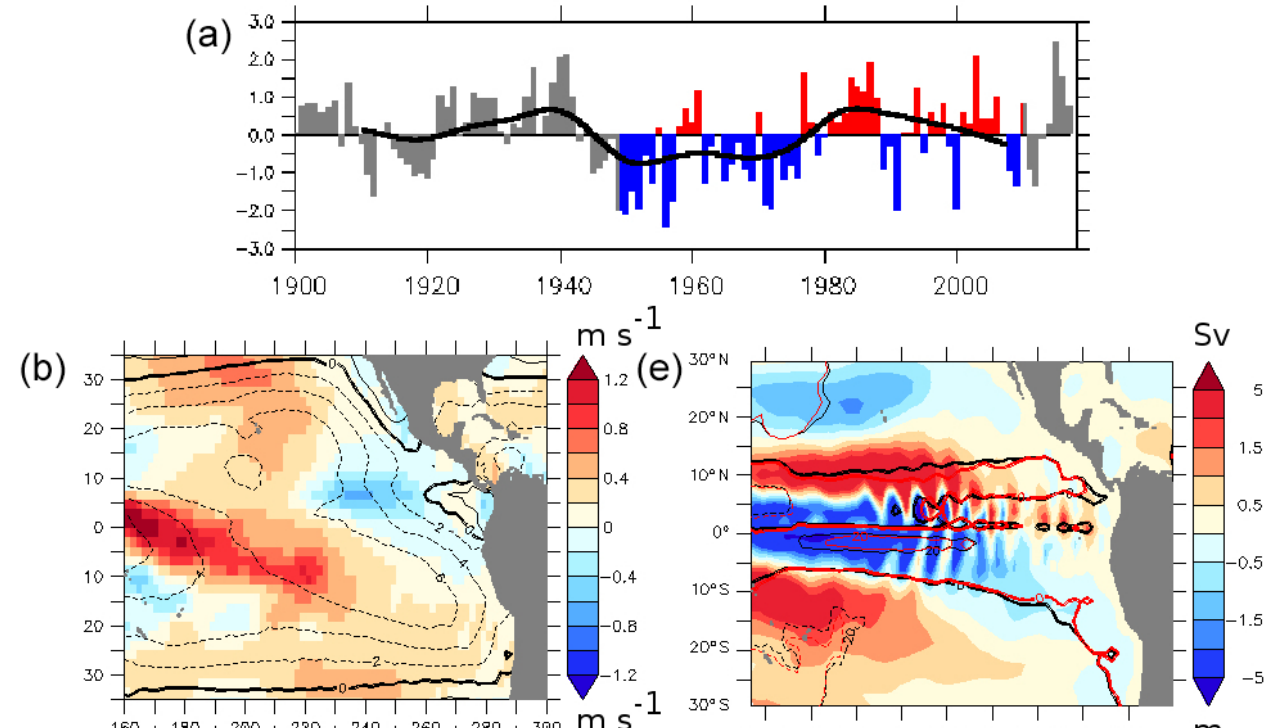

(c)

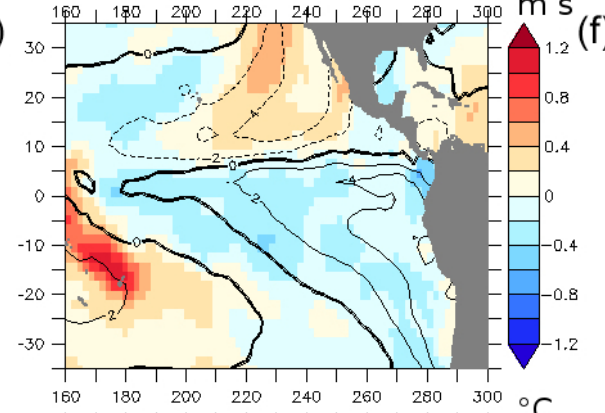

(d)

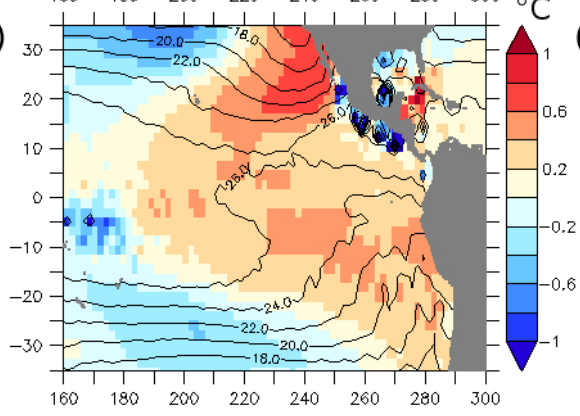

(f)

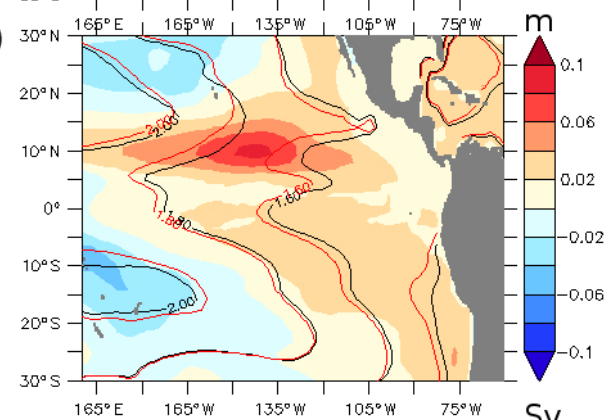

(g)

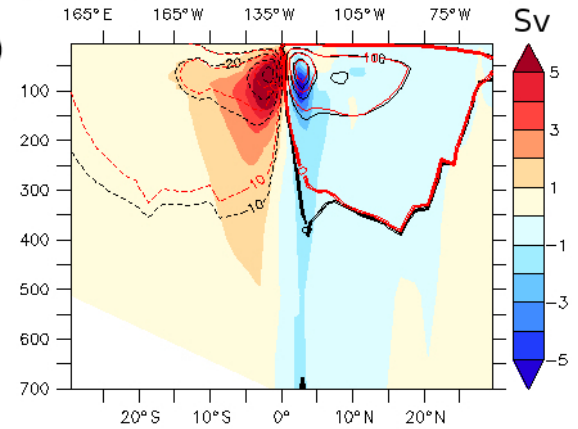

Figure 1. (a) Pacific Decadal Oscillation (PDO) index (1900-2017 annual averages; data from the "Joint Institute for the Study of the Atmosphere and Ocean - University of Washington, USA: http://research.jisao.washington.edu/data_sets/pdo). The 1948-2007 period has been highlighted (blue/red); the contour line is the smoothed PDO index (20-year running mean). (b) Average of the zonal $10 \mathrm{~m}$ wind component $\left(\mathrm{m} \mathrm{s}^{-1}\right)$ of the PDO positive (PDO_PLUS experiment) phase minus the PDO negative phase (PDO_MINUS experiment). The contour is the zonal wind component average $\left(\mathrm{m} \mathrm{s}^{-1}\right)$ 1948-2007. (c) Average of the meridional wind component $\left(\mathrm{m} \mathrm{s}^{-1}\right)$ of the PDO positive phase (PDO_PLUS experiment) minus the PDO negative phase (PDO_MINUS experiment). The contour is the meridional wind component average $\left(\mathrm{m} \mathrm{s}^{-1}\right)$ 1948-2007. (d) Average of the $10 \mathrm{~m}$ air temperature $\left({ }^{\circ} \mathrm{C}\right)$ of the PDO positive phase (PDO_PLUS experiment) minus the PDO negative phase (PDO_MINUS experiment). The contour is the average of the $10 \mathrm{~m}$ air temperature $\left({ }^{\circ} \mathrm{C}\right)$ 1948-2007. (e) Difference between the barotropic streamfunction (BSf) for PDO_PLUS and PDO_MINUS (Sv). The black contour represents PDO_MINUS BSf, and the red contour represents PDO_PLUS BSf. The sense of rotation is clockwise for positive values. (f) Difference between the sea surface height (SSH) for PDO_PLUS and PDO_MINUS (m). The black contour represents PDO_MINUS SSH, and the red contour represents PDO_PLUS SSH. (g) Difference between the meridional overturning (MOC) for PDO_PLUS and PDO_MINUS (Sv). The black contour represents PDO_MINUS MOC, and the red contour represents PDO_PLUS MOC. The sense of rotation is clockwise for positive values. All the of the differences between PDO_PLUS and PDO_MINUS are averaged over 50 years of integration time. 

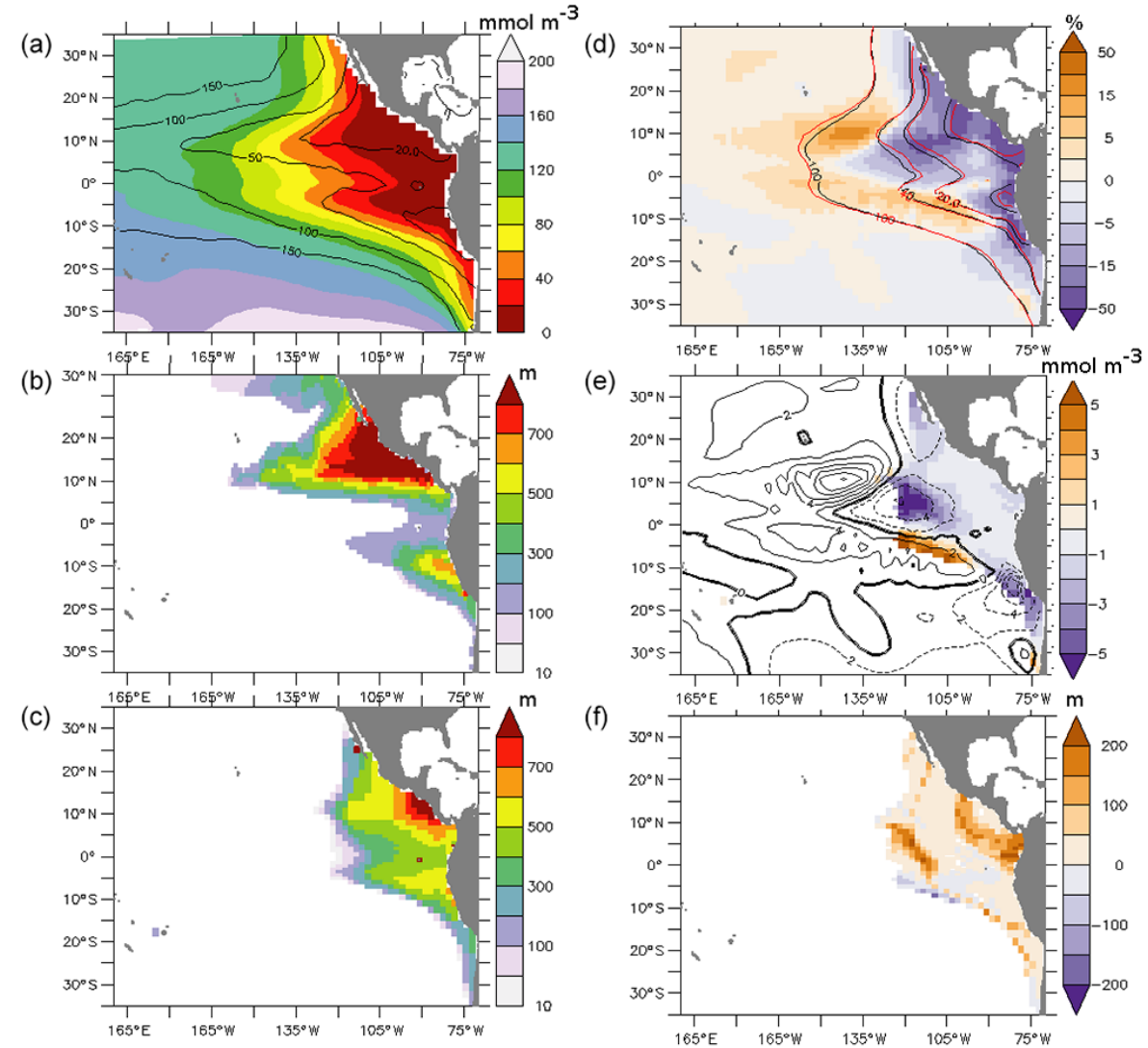

Figure 2. (a) Oxygen concentration $\left(\mathrm{mmol} \mathrm{m}^{-3}\right.$ ) at the end of the spin-up (average 100-700 $\mathrm{m}$ ). The contours represent the oxygen concentrations of the World Ocean Atlas (WOA; mmol m${ }^{-3}$ ) (average 100-700 m). (b) Thickness $(\mathrm{m}$ ) of the suboxic regions (oxygen lower than $20 \mathrm{mmol} \mathrm{m}^{-3}$ ) of the WOA and (c) at the end of the spin-up. (d) Difference in percentage between the oxygen concentrations in PDO_PLUS and in PDO_MINUS (average 100-700 m). Black contours represent the oxygen concentration in PDO_MINUS, and the red contours represent the oxygen concentration in PDO_PLUS $\left(\mathrm{mmol} \mathrm{m}^{-3}\right.$ ). (e) Difference between the oxygen concentration ( $\mathrm{mmol} \mathrm{m}^{-3}$ ) in PDO_PLUS and in PDO_MINUS vertically averaged over the suboxic regions SUB20 (defined as the region where the oxygen concentration is lower than $20 \mathrm{mmol} \mathrm{m}^{-3}$ at the end of the spin-up). The contours represent the differences between the oxygen concentrations ( $\mathrm{mmol} \mathrm{m}^{-3}$ ) in PDO_PLUS and PDO_MINUS (average 100-700 m). (f) Difference between the thickness (m) of the suboxic regions in PDO_PLUS and PDO_MINUS. All of the differences between PDO_PLUS and PDO_MINUS are averaged after 50 years of integration time.

model). The oxygen concentration in the SUB20 regions decreases by $2-10 \mathrm{mmol} \mathrm{m}^{-3}$ in PDO_PLUS compared with PDO_MINUS (0.04 to $\left.0.2 \mathrm{mmol} \mathrm{m}^{-3} \mathrm{yr}^{-1}\right)$. Conversely, in the mid-Pacific Ocean oxygen concentrations are $2 \%-20 \%$ higher in PDO_PLUS. This increase is localized $\left(5-10^{\circ} \mathrm{N}\right.$ and $5-10^{\circ} \mathrm{S}$ and eastward of $160^{\circ} \mathrm{W}$ ).

Our results can be put in perspective with observations. An oxygen decrease of $1 \mathrm{mmol} \mathrm{m}^{-3} \mathrm{yr}^{-1}$ has been monitored in the eastern equatorial region $\left(85^{\circ} \mathrm{W}, 2^{\circ} \mathrm{S}\right.$ to $\left.8^{\circ} \mathrm{S}\right)$ since 1976 (Czeschel et al., 2012). Schmidtko et al. (2017) also found a global decrease of the integrated oxygen concentration in the water column between 1960s and 2010s. This decrease was of the order of $0.2 \mathrm{mmol} \mathrm{m}^{-3} \mathrm{yr}^{-1}$ in the equatorial Pacific Ocean at $300 \mathrm{~m}$ depth. Similarly, Ito et al. (2017) showed that oxygen has declined at $400 \mathrm{~m}$ depth by $0.2 \mathrm{mmol} \mathrm{m}^{-3} \mathrm{yr}^{-1}$ since 1958 in the eastern Pacific Ocean; at $100 \mathrm{~m}$ depth, oxygen has decreased by up to $0.4 \mathrm{mmol} \mathrm{m}^{-3} \mathrm{yr}^{-1}$. However, Ito et al. (2017) observed a localized oxygen increase at $10^{\circ} \mathrm{N}$, similar to the one that we described above. Our simulations suggest that a shift from a negative to a positive phase of the PDO may be responsible for a large fraction of the observed oxygen decrease.

\section{Regulation of the oxygen levels}

The oxygen level below the euphotic zone is determined by the balance between consumption (respiration) and supply (transport). The supply is decomposed into advective, diapycnal and isopycnal diffusion terms. The analysis is based on the average of the 50 years of integration time. 


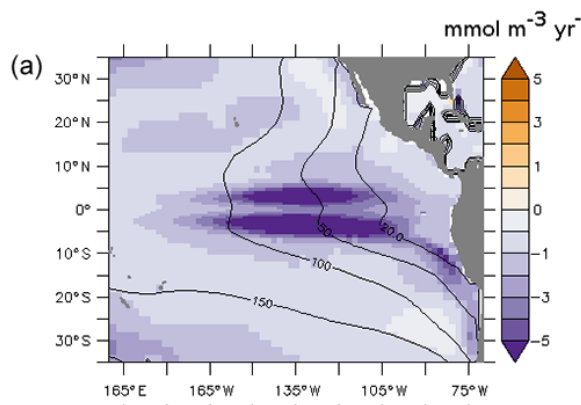

(b)

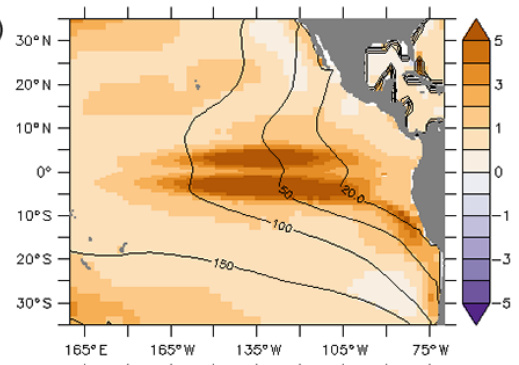

(c)

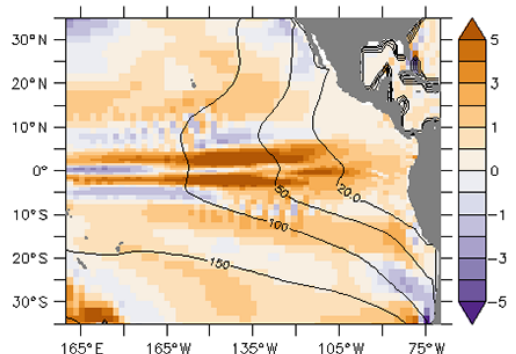

(d)

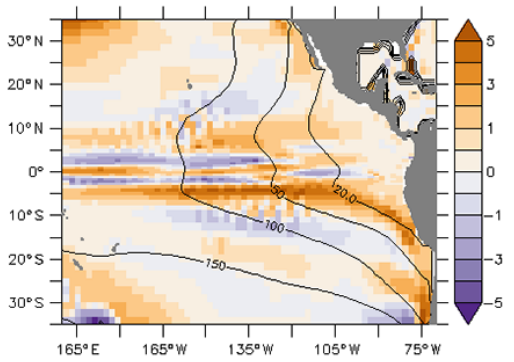

(e)

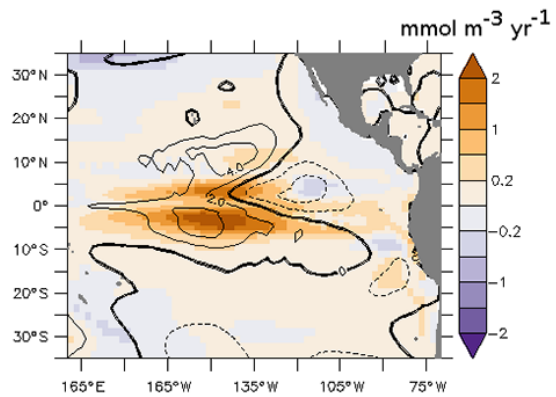

(f)

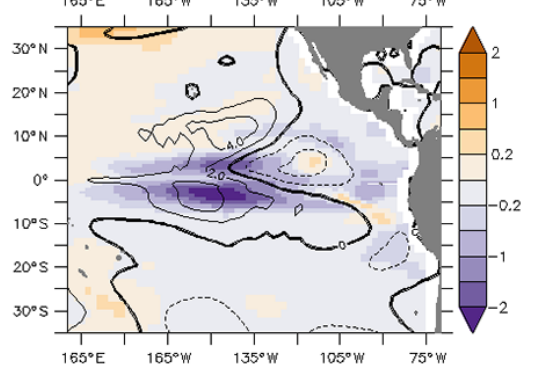

(g)

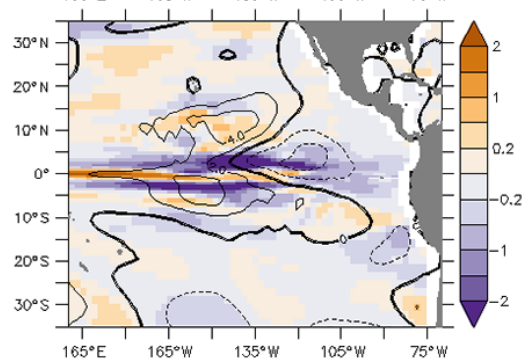

(h)

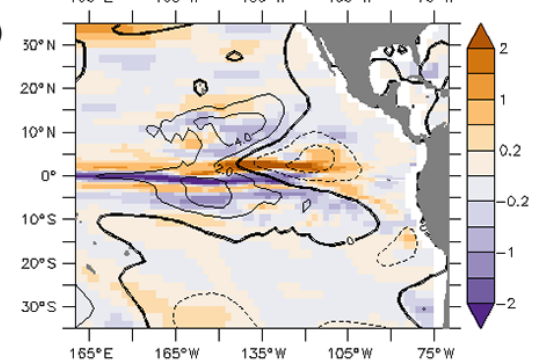

Figure 3. Budget of the oxygen concentration (average $100-700 \mathrm{~m} ;\left(\mathrm{mmol} \mathrm{m}{ }^{-3} \mathrm{yr}^{-1}\right)$ at the end of the spin-up (a-d) and the difference between PDO_PLUS and PDO_MINUS averaged over 50 years of integration time (e-f). (a, e) Respiration; (b, f) total supply; (c, g) advective processes; and (d, h) diffusive processes. The oxygen concentration $\left(\mathrm{mmol} \mathrm{m}^{-3}\right)$ is displayed using the contours in (a)-(d). The oxygen difference between PDO_PLUS and PDO_MINUS $\left(\mathrm{mmol} \mathrm{m}^{-3}\right)$ is displayed using the contours in (e)-(f). As a note of caution, a positive value corresponds to a source of oxygen while a negative value corresponds to a sink in (a)-(d), while differences between the two experiments are displayed in (e)-(f).

\subsection{Intermediate (100-700 m) tropical Pacific Ocean}

Respiration processes remove oxygen (Fig. 3a), especially in the tropical regions (up to $10 \mathrm{mmol} \mathrm{m}^{-3} \mathrm{yr}^{-1}$ in the $100-$ $700 \mathrm{~m}$ layer), as biological production is high along the Equator and close to the coast. In the PDO_PLUS experiment the basin-scale circulation is more sluggish than in PDO_MINUS (see Sect. 3), leading to a decrease in the concentration of nutrients in the euphotic zone (see Sect. 7). The respiration term becomes "less negative" in PDO_PLUS (positive anomaly of $1-2 \mathrm{mmol} \mathrm{m}^{-3} \mathrm{yr}^{-1}$ in the equatorial region; Fig. 2d).

The consumption of oxygen is compensated for by supply processes (Fig. 3b), which are partly performed by advective processes (Fig. 3c) that dominate the supply between $5^{\circ} \mathrm{N}$ and $5^{\circ} \mathrm{S}$ and in the eastern part of the basin; this shows the preponderant role of the equatorial current system regarding supplying oxygen to the oxygen-depleted regions (Cabre et al., 2015; Shigemitsu et al., 2017). Conversely, the diffusive processes (isopycnal and diapycnal mixing) dominate the supply outside of the equatorial region (poleward of $10^{\circ}$; 
Fig. 3d). The ocean currents shape the thermocline and high oxygen concentrations are transferred by isopycnal diffusion from the core of the EUC to the poleward intermediate ocean. The PDO_PLUS-PDO_MINUS positive oxygen anomaly in the western part of the basin is caused by the decrease in the respiration ("less negative" values), which is not completely compensated for by the decrease in the supply terms.

\subsection{SUB20 regions}

The contribution of each process was vertically and zonally averaged over the SUB20 region of the Pacific Ocean (Fig. 4a) and multiplied by the longitudinal extension of the SUB20 of the experiment PDO_MINUS. The total supply term (black line in Fig. 4a) is characterized by a large supply in the equatorial region, between $10^{\circ} \mathrm{N}$ and $10^{\circ} \mathrm{S}$, due to advective processes (red line in Fig. 4a). The role of the westward south and north equatorial currents is clearly apparent at $5^{\circ} \mathrm{N}$ and $5^{\circ} \mathrm{S}$. At this location the thermocline exhibits a strong slope with strong oxygen gradients, fostering isopycnal diffusion (blue line in Fig. 4a), removing oxygen from the Equator (and the EUC) and transferring it to the deeper, adjacent regions. The effect of the jets and the isopycnal diffusion add up and cause the strong peak in oxygen supply, located between 5 and $10^{\circ} \mathrm{S}$ (and to a lesser extent between 5 and $10^{\circ} \mathrm{N}$ ). The role of the oxygen supply by diapycnal diffusion (green line in Fig. 4a) is relatively small in the equatorial region (about $20 \%$ of the total supply), but more significant between 30 and $10^{\circ} \mathrm{S}$ (about one-third of the total supply) and dominant north of $10^{\circ} \mathrm{N}$ (Fig. 4b). Between 10 and $30^{\circ} \mathrm{S}$, the isopycnal diffusion term (blue line in Fig. 4a) plays a dominant role, possibly due the outcrop of isopycnals and the formation of mode waters close to the southern part of SUB20. The importance of the isopycnal diffusion in setting the oxygen levels in the region off Chile (around $30^{\circ} \mathrm{S}$ ) has been previously highlighted by sensitivity tests to the Redi mixing coefficient (Gnanadesikan et al., 2012). Stramma et al. (2010) roughly estimated the oxygen budget $\left(30^{\circ} \mathrm{N}-30^{\circ} \mathrm{S}\right)$ in the suboxic regions based on observational data. Despite large uncertainties, the observational budget estimate points to an allocation of about $33 \%$ by advection, $22 \%$ by vertical mixing and $45 \%$ by eddy mixing (Brandt et al., 2015). In our model, averaging the SUB20 budget between $30^{\circ} \mathrm{N}$ and $30^{\circ} \mathrm{S}$ gives comparable magnitudes (Fig. 4b) (in PDO_MINUS $21 \%$ of the supply occurs by advection, $29 \%$ by diapycnal mixing and $50 \%$ by isopycnal mixing, strongly related to mesoscale activity).

In the PDO_PLUS experiment, the supply of oxygen by circulation processes decreases (black line in Fig. 4c) due to a reduction in the advective supply in the equatorial region (Fig. $4 \mathrm{~d}-$ red) and of the diapycnal and isopycnal diffusion poleward of $10^{\circ} \mathrm{N}$ and $10^{\circ} \mathrm{S}$ (green and blue lines in Fig. 4d, respectively). The primary production decreases as well, resulting in a positive anomaly of the respiration term (which is "less negative"; green line in Fig. 4c). The decrease in respi-
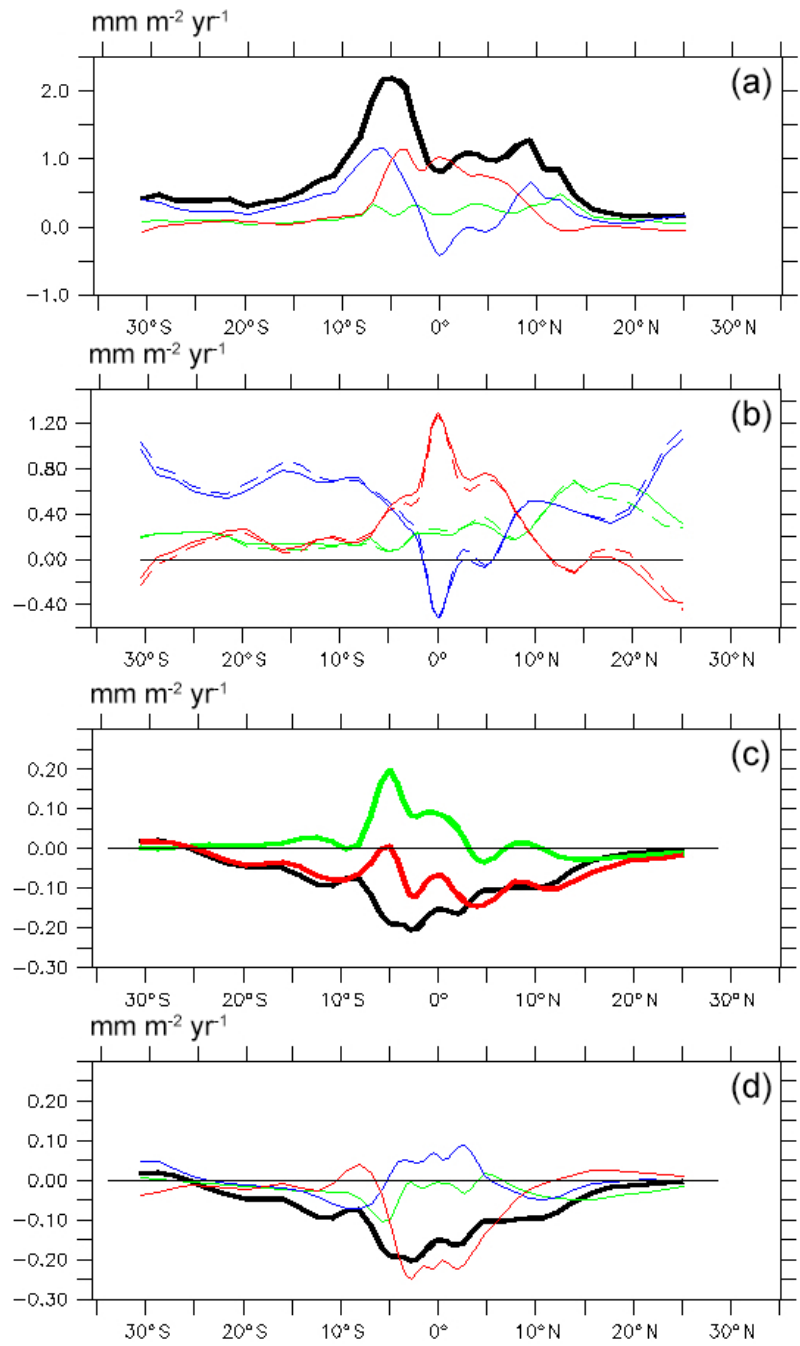

Figure 4. (a) Zonal integration of the vertically averaged oxygen supply in the suboxic regions SUB20 (oxygen lower than $20 \mathrm{mmol} \mathrm{m}^{-3} ; \mathrm{mmol} \mathrm{m}^{-2} \mathrm{yr}^{-1}$ ) at the end of the spin-up. Black represents total supply, red represents advective processes, blue represents isopycnal diffusion and green represents diapycnal diffusion. (b) Relative importance of the advective processes (red), isopycnal diffusion (blue) and diapycnal diffusion (green) in the total oxygen supply in SUB20 (the solid line represents the PDO_MINUS experiment, and the dashed line represents the PDO_PLUS experiment). (c) Zonal integration of the vertically averaged difference of oxygen supply/removal in PDO_PLUS minus PDO_MINUS (mmol m-2 $\mathrm{yr}^{-1}$ ) in SUB20. Black denotes supply, green is respiration and red represents supply + respiration. (d) Zonal integration of the vertically averaged difference of oxygen supply in PDO_PLUS minus PDO_MINUS $\left(\mathrm{mmol} \mathrm{m}^{-2} \mathrm{yr}^{-1}\right)$ in SUB20. Black is total supply, red denotes advective processes, blue is isopycnal diffusion and green is diapycnal diffusion.

ration nearly compensates for the reduced supply of oxygen, especially in the equatorial region; however, the decrease in the circulation supply terms is larger, leading to a net de- 
crease in oxygen levels in SUB20 (red line in Fig. 4c). In the $10-30^{\circ} \mathrm{N}$ region, about half of the oxygen decrease is caused by changes in the supply, while the other half is due to changes in respiration, triggered by changes in the advective processes (see Sect. 7). In the $10-30^{\circ} \mathrm{S}$ region, the decrease in the oxygen levels is principally due to a decrease in the isopycnal and mixing processes (Fig. 4d). As the ocean circulation is generally weaker in PDO_PLUS, the relative importance of diffusion increases in the PDO_PLUS experiment compared to PDO_MINUS (20\% of the supply occurs by advection, $27 \%$ by diapycnal mixing and $53 \%$ by isopycnal mixing; Fig. 4b)

\section{Temporal aspects}

\subsection{Intermediate (100-700 m) tropical Pacific Ocean}

In the western part of the basin $\left(160^{\circ} \mathrm{E}-140^{\circ} \mathrm{W}, 10^{\circ} \mathrm{N}-\right.$ $10^{\circ} \mathrm{S}$ ), oxygen concentrations decrease in PDO_PLUS compared with PDO_MINUS in the first few years of the experiment (initial shock, highlighting the timescale of the response of productivity to a change in circulation) and increase afterwards (Fig. 5a-d). The changes in the advective processes (blue line in Fig. 5e) are largely responsible for the total changes in the supply (bold black line in Fig. 5e). The decrease in respiration (green in Fig. 6e) offsets these changes, leading to net a positive anomaly (bold red line in Fig. 5e). After 50 years the positive anomaly is still growing but at a slower pace (Fig. 5a): diffusive processes (cyan) and more specifically diapycnal diffusion (pink) act in the same direction as the current-driven changes as a result of a less stratified upper ocean under PDO_PLUS conditions. (While the PDO_PLUS surface fluxes warm the surface ocean and foster a strong upper ocean stratification, the PDO_PLUS winds weaken the upwelling, warm the subsurface ocean and foster a weak upper ocean stratification. The latter effect overcompensates for the surface warming and explains that the ocean is less stratified under PDO_PLUS conditions compared to PDO_MINUS conditions).

\subsection{SUB20 regions}

The picture described above shows similarities to that of the equatorial region $\left(10^{\circ} \mathrm{N}-10^{\circ} \mathrm{S}\right)$ of SUB20, where a strong decrease in the oxygen supply (bold black line in Fig. 5f) due to advective processes (blue line in Fig. 5f) occurs. However, the role of diffusion (pink line in Fig. 5f) is larger in SUB20 compared with the mid-Pacific equatorial region. Respiration changes (green line in Fig. 5f) do not offset the weaker supply, as in the western tropical Pacific Ocean, leading to a net decrease in the oxygen concentration (Fig. 5a-d). In the northern part $\left(10-30^{\circ} \mathrm{N}\right)$ of SUB20 an increase in oxygen transport by advective processes (blue line in Fig. $5 \mathrm{~g}$ ) is compensated for by a strong decrease due to diffusion processes (less mixing), leading to a net decrease in the oxygen supply.
Primary production and respiration increases (see Sect. 7), reinforcing the decrease in oxygen levels. In the southern part $\left(10-30^{\circ} \mathrm{S}\right)$ of SUB20 the decrease in the oxygen supply by advective transport (blue line in Fig. 5h) is accompanied by a strong decrease in the supply by diapycnal (pink in Fig. 6h) and isopycnal mixing (cyan line in Fig. 5h). The adjustment occurs on a (multi) decadal timescale (Fig. 5a-d). The strong changes in the supply mechanisms in the northern/southern part of the SUB20 regions are likely linked to the stronger influence of the subtropical regime in PDO_PLUS than in PDO_MINUS in SUB20 (see Sect. 3), which explains the "initial shock" related to a change of regime.

The simulated PDO-induced changes are significant after at least 5 years (in the equatorial Pacific Ocean) to a few decades (in the southern part of the suboxic regions). Significant changes occurred after a similar timescale in the study by Ridder and England, 2014. This suggests that higherfrequency climate oscillations such as the El Niño-Southern Oscillation (ENSO) - or "short-lasting" PDO events - have a very limited impact on oxygen concentrations of the suboxic eastern tropical Pacific, which is in agreement with Deutsch et al. (2011) and Ito and Deutsch (2013). However, ENSO may have an impact on the surface air/sea oxygen exchanges (Eddebar et al., 2017) and "short-lasting" PDO events (less than 10 years) may impact the oxygen concentration of the upper thermocline in the mid-Pacific Ocean (Duteil et al., $2014 \mathrm{~b})$. In the southern region $\left(10-30^{\circ} \mathrm{S}\right)$, the system is still losing oxygen after 50 years of integration time suggesting that extra-tropical processes are involved. Getzlaff et al. (2016) showed that a vigorous South Pacific subtropical gyre, driven by an increase in the Southern Hemisphere westerlies, supplies oxygen to the tropics. Yamamoto et al. (2015) and Keller et al. (2016) showed that high latitudes may constrain tropical suboxic regions at multi-decadal to centennial timescale.

\section{Productivity and upwelling}

As previously seen, changes in respiration play a significant role in setting the oxygen levels. Respiration either compensates for the changes in supply in the equatorial region or acts in synergy with the decrease in supply to deplete oxygen in the northern part of SUB20 in the PDO_PLUS experiment. While the changes in the oxygen supply and transport are primarily linked to changes in the structure of the interior ocean, the change in respiration is principally linked to the surface and upper thermocline productivity, which ultimately depends on the supply of nutrients to the mixed layer.

\subsection{Upwelling strength and seasonality}

In the PDO_PLUS experiment, the nutrient supply decreases over most of the basin, leading to a decrease in the nutrient uptake and the productivity. The decrease in the supply 
(a)

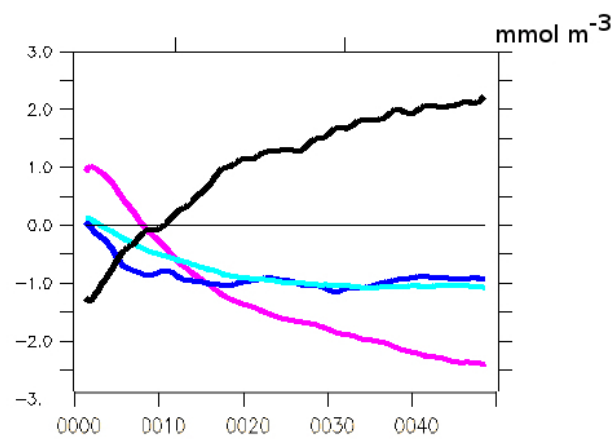

(b)

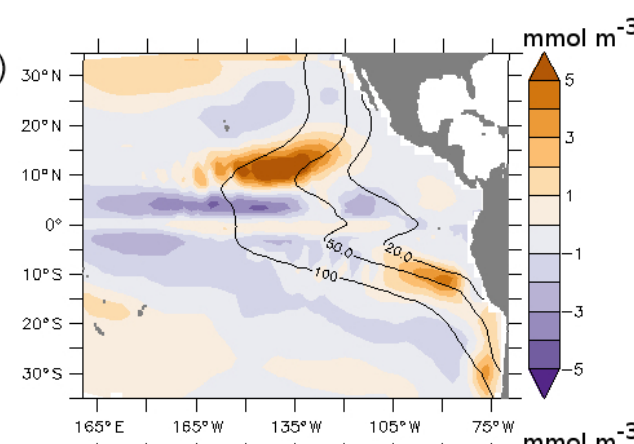

(c)

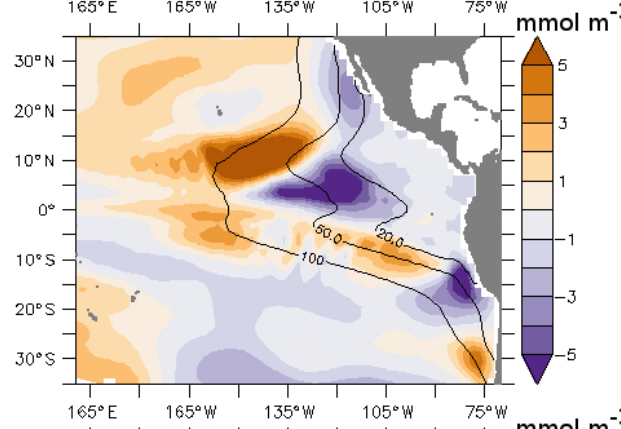

(d)

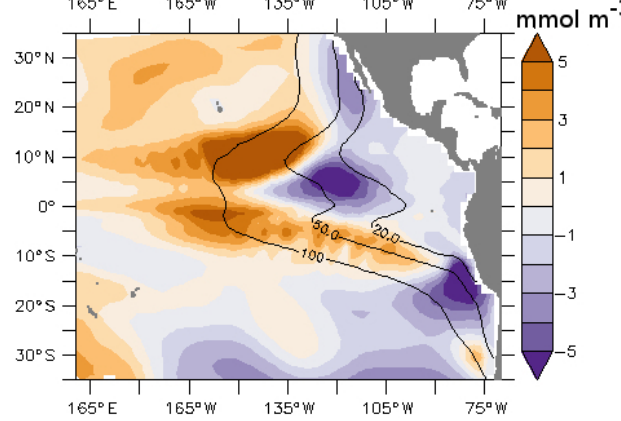

(e)

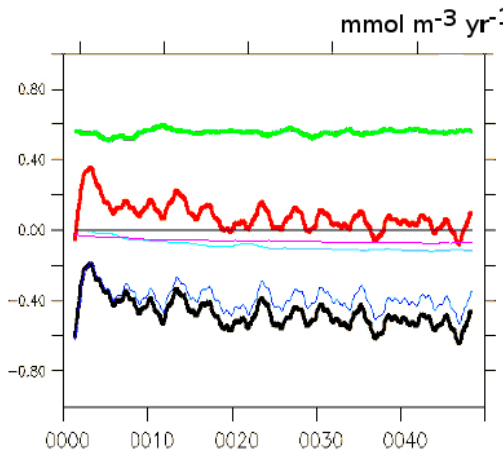

(f)

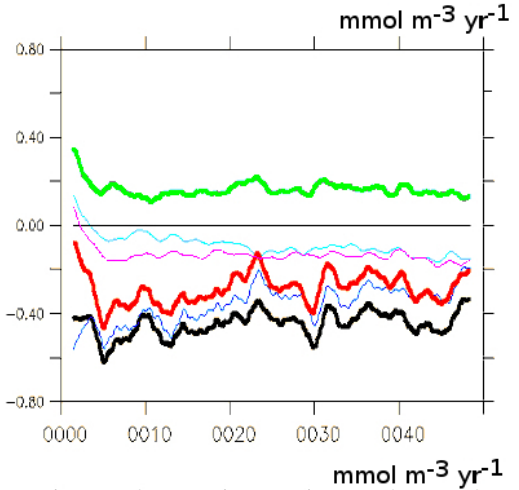

(g)

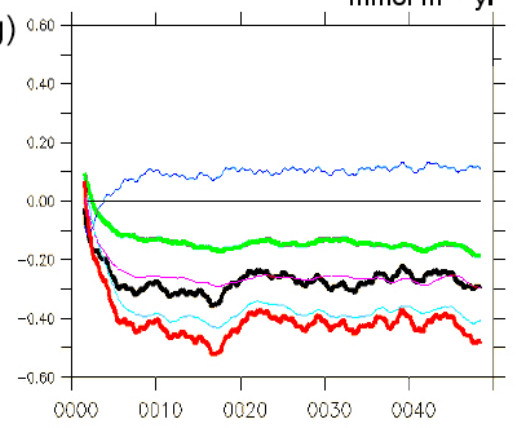

(h)

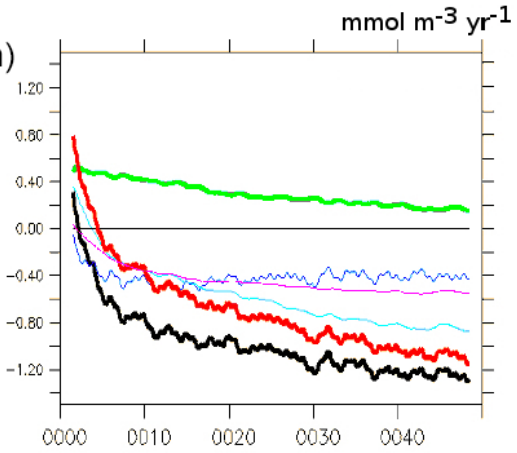

Figure 5. (a) Time series (50 years) of the difference between PDO_PLUS and PDO_MINUS regarding the oxygen concentration $\left(\mathrm{mmol} \mathrm{m}{ }^{-3}\right)$ in the EQ region (average $10^{\circ} \mathrm{N}-10^{\circ} \mathrm{S}, 160^{\circ} \mathrm{E}-140^{\circ} \mathrm{W}, 100-700 \mathrm{~m}$; black), the SUB20EQ region (equatorial part of SUB20: $10^{\circ} \mathrm{S}-10^{\circ} \mathrm{N}$; dark blue), the SUB20N region (northern part of SUB20: 10-30 N; cyan) and the SUB20S region (southern part of SUB20: 10-30 $\mathrm{S}$; pink). (b, c, d) Oxygen $\left(\mathrm{mmol} \mathrm{m}^{-3}\right.$ ) difference (average 100-700 m) between PDO_PLUS and PDO_MINUS after (b) 2 years, (c) 10 years and (d) 20 years of integration time. (e-h) Time series (50 years) of the difference between the PDO_PLUS and the PDO_MINUS oxygen budget $\left(\mathrm{mmol} \mathrm{m}^{-3} \mathrm{yr}^{-1}\right.$ ) in (e) EQ, (f) SUB20EQ, (g) SUB20N and (h) SUB20S. The bold black line is total supply, the blue line is advective supply, the pink line is diapycnal diffusion, the cyan line is diapycnal + isopycnal diffusion, the bold green line is respiration and the bold red line represents supply + respiration. 
$\%$

(a)

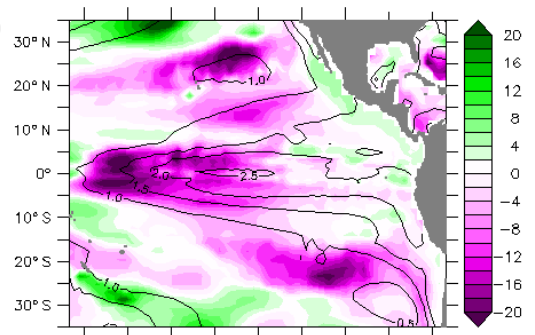

(b)

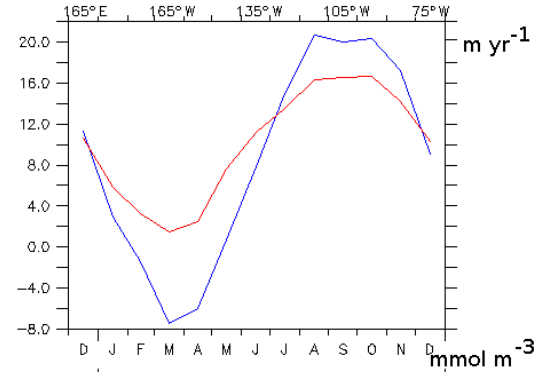

(c)

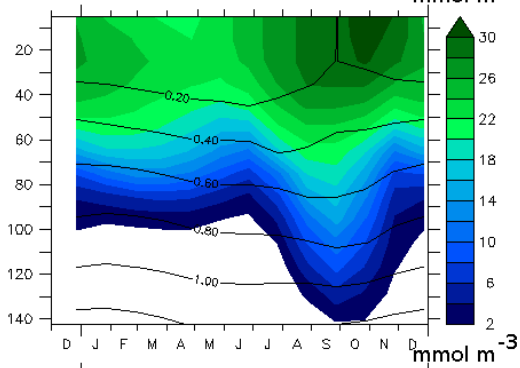

(d)

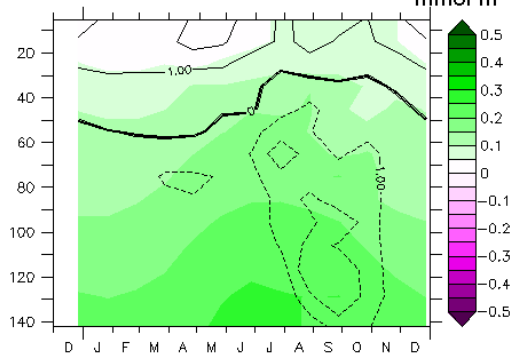

(e)

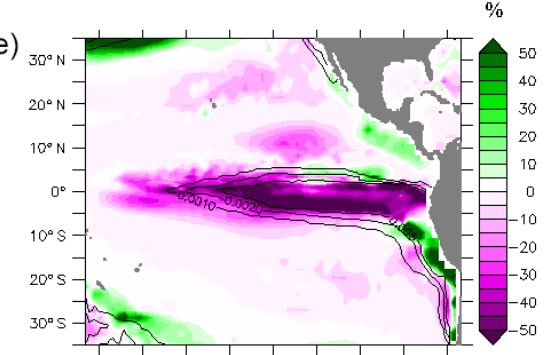

(f)

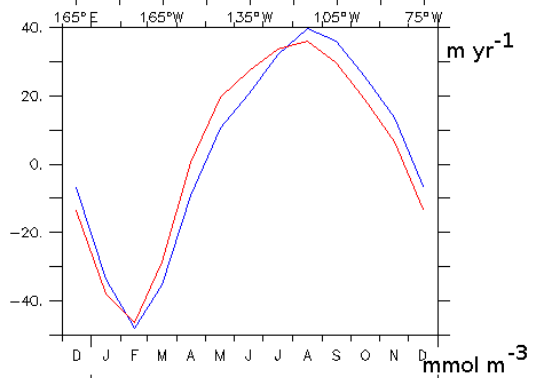

(g)

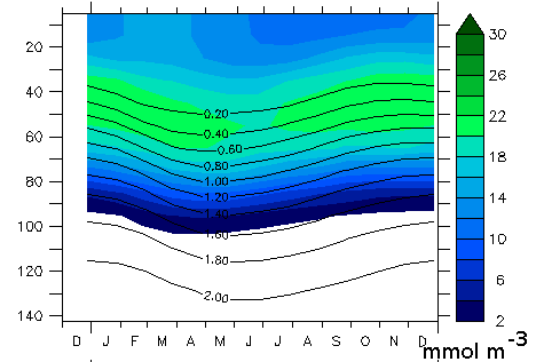

(h)

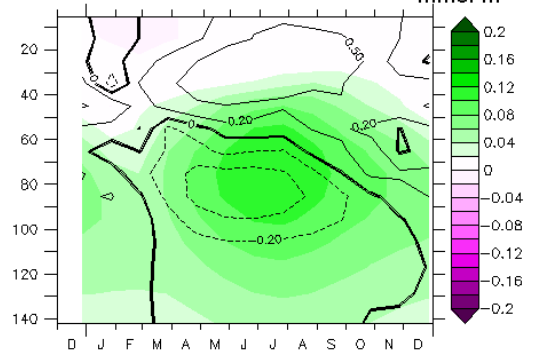

Figure 6. (a) Difference (\%) of the vertically integrated phytoplankton concentration between PDO_PLUS and PDO_MINUS (average of 50 years of integration time). The vertically integrated phytoplankton concentration of PDO_MINUS is shown using the contours $\left(\mathrm{mmol} \mathrm{m}^{-2}\right)$. (b) Difference (\%) of the surface phosphate concentration between PDO_PLUS and PDO_MINUS (average of 50 years of integration time). The surface phosphate concentration of PDO_MINUS is shown using the contours $\left(\mathrm{mmol} \mathrm{m}^{-2}\right)$. (c, e, g) Average of the 10-20 $\mathrm{S} / 90-$ $60^{\circ} \mathrm{W}$ region and $(\mathbf{d}, \mathbf{f}, \mathbf{h})$ the $10^{\circ} \mathrm{N}: 20^{\circ} \mathrm{N} / 120-90^{\circ} \mathrm{W}$ region $(\mathbf{c}, \mathbf{d})$ upwelling $\left(\mathrm{m} \mathrm{yr}^{-1}\right.$; blue - PDO_MINUS, red - PDO_PLUS) and (e, f) phytoplankton concentration ( $\mathrm{mmol} \mathrm{m}^{-3}$; contours represent phosphate concentration) at the end of the spin-up. (g, h) Difference between PDO_PLUS and PDO_MINUS phytoplankton concentration $\left(\mathrm{mmol} \mathrm{m}^{-3}\right.$; contours represent difference between the PDO_MINUS and PDO_PLUS phosphate concentration).

is caused both by a slowing-down of the circulation and by a thermocline deepening (as seen in Sect. 3). However, counter intuitively, nutrient levels increase and production is slightly (2\%-5\%) higher in PDO_PLUS in the eastern upwelling systems. Figure 6a presents similarities with the imprint of the PDO on the deseasonalized chlorophyll concentration inferred from satellite data (Thomas et al., 2012). Thomas et al. (2012) found that a positive phase of the PDO is associated with a general decrease in the chlorophyll concentration in the tropical Pacific Ocean. However, in the region located between 15 and $30^{\circ} \mathrm{N}$ and east of $140^{\circ} \mathrm{W}$, and in the region south of $10^{\circ} \mathrm{S}$ and east of $120^{\circ} \mathrm{W}$ the correlation between PDO and deseasonalized chlorophyll is positive (Fig. 7 in Thomas et al., 2012). Furthermore, other climate oscillations, such as the North Pacific Gyre Oscillation (NPGO) constrain the strength of the upwelling cells in the ETNP in addition to the PDO (DiLorenzo et al., 2008; Macias et al., 2012). 

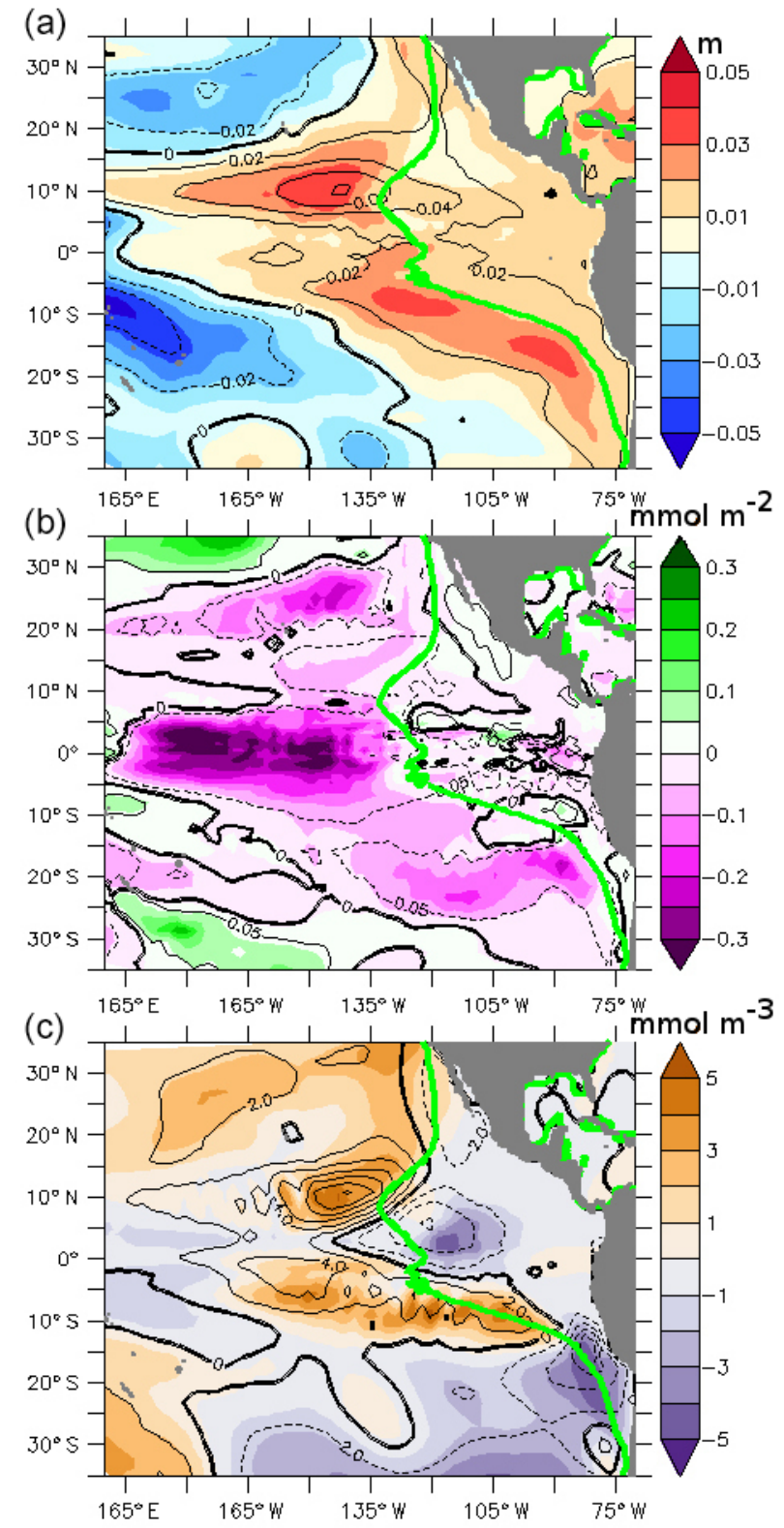

Figure 7. (a) Difference between the sea surface height (m) of the PDO_PLUS50 and the PDO_MINUS50 experiments (colored legend) and the PDO_PLUS and PDO_MINUS experiments (contours). (b) Difference between the vertically integrated phytoplankton concentration $\left(\mathrm{mmol} \mathrm{m}^{-2}\right)$ of the PDO_PLUS50 and PDO_MINUS50 experiments (colored legend) and the PDO_PLUS and PDO_MINUS experiments (contours). (c) Difference between the average $100-700 \mathrm{~m}$ oxygen concentration $\left(\mathrm{mmol} \mathrm{m}^{-3}\right)$ for the PDO_PLUS50 and PDO_MINUS50 experiments (colored legend) and the PDO_PLUS and PDO_MINUS experiments (contours).

The productivity increase in PDO_PLUS is due to the change in the seasonality of the upwelling system in our experiments. The eastern tropical South Pacific (ETSP) region (average $10-30^{\circ} \mathrm{S}, 90-60^{\circ} \mathrm{W}$ ) is characterized by a strong downwelling in May/April and a strong upwelling in August/September in PDO_MINUS (Fig. 6c). Conversely, in PDO_PLUS, the ETSP is characterized by a weaker upwelling which persists throughout the year, continuously supplying nutrients into the mixed layer and the upper ocean and creating a positive anomaly in nutrients and productivity (Fig. 6e and g). In the eastern tropical North Pacific (ETNP) $\left(10-30^{\circ} \mathrm{N}, 120-90^{\circ} \mathrm{W}\right)$, a strong upwelling occurs 1 month earlier in PDO_PLUS than in PDO_MINUS (Fig. 6d), leading to an increase in the nutrient concentrations in the upper ocean (Fig. $6 \mathrm{f}$ and $\mathrm{h}$ ) in a season when irradiance is high, fostering primary production. The positive PDO years used to construct the PDO_PLUS forcing are made up of $30 \%$ of positive NPGO years, which may explain the shift in the upwelling seasonality and the stimulation of productivity in the ETNP (Chenillat et al., 2012).

\subsection{Role of local vs. large scale circulation}

In order to disentangle the changes in the local forcing related to upwelling, and the remote forcing (trade winds) in the eastern Pacific Ocean oxygen levels and productivity, we perform two supplementary experiments, PDO_MINUS50 and PDO_PLUS50. These experiments are similar to PDO_MINUS and PDO_PLUS. However, where oxygen is lower than $50 \mathrm{mmol} \mathrm{m}^{-3}$, anywhere in the water column, at the end of the spin-up (green line in the Fig. 7ac), the MEAN surface forcing is employed (see Sect. 2). As the resolution of the CORE forcing is relatively coarse $\left(1.9^{\circ}\right)$ and the NEMO circulation model interpolates the forcing on the ocean grid, we did not perform any explicit smoothing between the regions where the MEAN and the PDO_MINUS/PDO_PLUS forcings are used.

The PDO_PLUS50-PDO_MINUS50 SSH anomaly (Fig. 7a) presents a similar pattern to the PDO_PLUSPDO_MINUS SSH anomaly. However, the amplitude of PDO_PLUS50-PDO_MINUS50 is weaker than the amplitude of PDO_PLUS-PDO_MINUS in the eastern part of the Pacific basin (east of the green line - Fig. 7a), showing that both remote and local forcings control the circulation properties east of $130^{\circ} \mathrm{W}$ in the equatorial region. This is consistent with the results of Zhang and McPhaden (2008) who showed that both the large scale circulation and the local wind stress anomalies impact the surface temperature variability in the NINO3 $\left(150-90^{\circ} \mathrm{W} ; 5^{\circ} \mathrm{N}-5^{\circ} \mathrm{S}\right)$ region.

The PDO_PLUS50-PDO_MINUS50 productivity anomaly (Fig. 7b) and the PDO_PLUS-PDO_MINUS productivity anomaly display similar patterns in the western part of the basin. However, in the eastern part (east of the green line - Fig. 7), the productivity is nearly identical in PDO_PLUS50 and PDO_MINUS50 suggesting that the change in productivity in the SUB20 regions is mostly driven by local forcings. The nutrients are indeed supplied into the euphotic zone by the upwelling systems, which are primarily 
driven by alongshore wind stress and curl (e.g Albert et al., 2010; Belmadani et al., 2014).

The oxygen concentration depends on both changes in circulation and in productivity. In the eastern part of the basin (east of the green line - Fig. 7), the PDO_PLUS50-PDO_MINUS50 oxygen anomaly is similar to the PDO_PLUS-PDO_MINUS oxygen anomaly in the equatorial and southern part of SUB20: a change in local forcings has almost no impact on the simulated oxygen fields. These experiments suggest that the changes in oxygen concentration related to the change from a negative to a positive PDO phase are not directly related to changes in the coastal productivity and in the upwelling strength, but rather to changes in the large-scale circulation in the equatorial and southern part of SUB20. Conversely, in the northern part of SUB20, local forcings play a dominant role as the PDO_PLUS50-PDO_MINUS50 oxygen anomaly is positive while the PDO_PLUS-PDO_MINUS anomaly is negative.

\section{Summary of the processes at play and conclusions}

In this study we tested whether the PDO impacts the oxygen concentration in the eastern part of the Pacific Ocean. We use the forced ocean model NEMO coupled to a simple NPZD (Nutrient Phytoplankton Zooplankton Detritus) model. After spin-up, the NEMO-NPZD model was forced by "typical" PDO positive (experiment PDO_PLUS) and negative (experiment PDO_MINUS) conditions derived from the COREv2 atmospheric forcings. A PDO-positive phase is characterized by an approximate $5 \%$ to $10 \%$ decrease in the zonal and meridional wind speed over the Pacific Ocean, while the sea surface temperature increases by $0.2^{\circ} \mathrm{C}$. A PDOnegative event shows the opposite pattern. In agreement with observations (McPhaden and Zhang, 2002), the circulation of the tropical Pacific Ocean is more sluggish (by $5 \%$ to $10 \%$ ) in the PDO_PLUS experiment compared with the PDO_MINUS experiment. After 50 years of integration time, the volume of the suboxic regions (oxygen lower then $20 \mathrm{mmol} \mathrm{m}^{-3}$ ) is $7 \%$ larger and the oxygen concentration decreases by $5 \%$ to $50 \%$ in the suboxic regions in PDO_PLUS compared with PDO_MINUS.

Recent analyses of the observational datasets showed that the oxygen concentration has decreased by about $5 \%$ in the eastern equatorial Pacific Ocean region since 1960 (Schmidtko et al., 2017; Ito et al., 2017). We show here that a PDO_PLUS PDO event lasting for 50 years may impact the suboxic region by at least a similar order of magnitude. The shift from a PDO-negative phase (prevailing conditions before 1975) to a PDO positive phase (prevailing conditions since 1975) may therefore explain a significant percentage of the large deoxygenation that has occurred over the last few decades.

The simulated suboxic regions are divided into equatorial $\left(10^{\circ} \mathrm{N}-10^{\circ} \mathrm{S}\right)$, northern $\left(10-30^{\circ} \mathrm{N}\right)$ and southern $\left(10-30^{\circ} \mathrm{S}\right)$

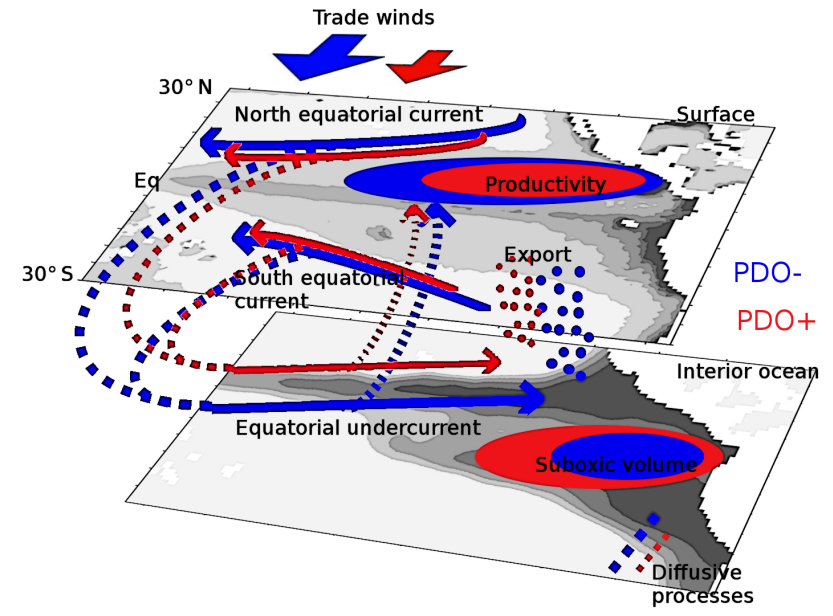

Figure 8. Summary of the processes at play during a PDO positive (red) and negative phase (blue).

parts. The oxygen levels of each subregion are constrained by different processes. In the equatorial part, the oxygen levels are set by advective processes (Cabre et al., 2015; Shigemitsu et al., 2017). In the PDO_PLUS experiment, the slowingdown of the equatorial current system (and more particularly of the equatorial undercurrent) decreases the supply of oxygen (Fig. 8). Simultaneously, the supply of nutrients decreases, leading to a decrease in productivity and respiration. In the eastern part of the basin (in the suboxic regions), the decrease of supply dominates the change in respiration leading to a net oxygen decrease. Inversely, the change in respiration is dominant in the mid-Pacific Ocean, highlighting the importance of the parameterization of the biogeochemical processes (Kriest et al., 2010; Kriest and Oschlies, 2015) and more particularly the response of the phytoplankton growth to a change in nutrient concentration.

The southern part of the suboxic regions is mostly constrained by isopycnal diffusion processes (Gnanadesikan et al., 2012). In the PDO_PLUS experiment, the supply of oxygen by isopycnal processes from the equatorial regions and the subtropical gyres to the tropics decreases compared to PDO_MINUS. In the northern part, the role of diapycnal processes is dominant. In the PDO_PLUS experiment, the oxygen decrease is caused by changes in the upwelling system, stimulating productivity and respiration.

The general slowdown of the large-scale circulation caused by a decrease in the intensity of the trade winds is not reflected in the upwelling strength (Narayan et al., 2010), which is mainly forced by local processes. The strength and seasonality of the upwelling constrain the amount of productivity and the subsequent respiratory oxygen consumption in the suboxic regions. A shift in the upwelling seasonality explains the larger respiration in PDO_PLUS compared with PDO_MINUS in the northern part of the suboxic region. This shift is potentially linked to the NPGO (DiLorenzo et al., 
2008), a decadal climate oscillation which has a signature that is implicitly contained in the "typical" PDO forcing. Using two supplementary experiments where the PDO_PLUS and PDO_MINUS forcings are only applied in the midPacific Ocean above the tropical Pacific low-oxygen areas, we highlighted that a change in the large-scale wind pattern constrains changes in the equatorial and southern oxygen levels, while oxygen changes in the northern part are constrained by local processes.

One of the largest limitations of our study is that the idealized PDO forcings were prepared using a relatively short period extending from 1948 to 2007 (the COREv2 dataset). The implicit contribution of statistically independent climate oscillations such as the NPGO (DiLorenzo et al., 2008) can therefore not be completely ruled out.

Finally, another limitation is the resolution of the model. The role of mesoscale activity has been previously demonstrated in the supply of oxygen to the suboxic regions of the eastern Pacific Ocean (Montes et al., 2014; Bettencourt et al., 2015; Vergara et al., 2016). The relative increase in the isopycnal diffusive supply in a PDO-positive phase suggests the importance of the role of mesoscale activity during this period.

Our study suggests that the shift from a prolongated (multi-decadal) negative to a prolongated positive PDO phase is accompanied by a decrease in the oxygen levels in the eastern tropical Pacific Ocean. Several multi-decadal PDO shifts have occurred in the last century. For instance, the period from 1943 to 1976 is characterized by a negative PDO phase, while a positive PDO phase occurred from 1977 to 2011 (Fig. 1a). Such shifts have occurred roughly every few decades during the last 1000 years, as shown by PDO reconstructions (MacDonald and Case, 2005). An open question is whether the succession of these alternate shifts may cause a change in the oxygen concentration on centennial to millennial timescales.

Our study can be compared to the study of Deutsch et al. (2011) (hereafter referred to as D2011). Based on a 19592005 hindcast experiment, D2011 showed that the global suboxic volume $\left(\mathrm{O}_{2}<5 \mathrm{mmol} \mathrm{m}^{-3}\right), 95 \%$ of which is contained in the northeastern tropical Pacific Ocean $\left(0\right.$ to $30^{\circ} \mathrm{N}$, $140^{\circ} \mathrm{W}$ to the coast), is controlled by the depth of the thermocline that constrains the productivity and the amount of oxygen respired around the suboxic volume. The depth of the thermocline is strongly related to the strength of the PDO, which explains $24 \%$ of the variability of the suboxic volume in the hindcast simulation of D2011. In D2011, a PDOnegative phase was characterized by a large extent of the suboxic regions resulting from enhanced respiration with only negligible effects of changes in oxygen supply. Our results differ from D2011 because the increase in the respiration in a PDO-negative phase (higher primary production) is more than compensated for by an increase in the oxygen supply due to advective/diffusive processes, which ultimately leads to elevated oxygen levels and smaller suboxic regions in a
PDO-negative state. Considering that the models used by D2011 and those used in our study are similar with similar grid resolution, the balance between changes in the oxygen consumption (dominant effect in D2011) and the transport (dominant effect in our study) depends on (i) the response of primary productivity and export production to a nutrient increase, and (ii) the depth of the suboxic regions, as respiration changes are stronger, and more difficult to compensate for by oxygen supply changes, at shallower than at greater depths. While the biogeochemical model used in our study contains fully prognostic nutrient, phytoplankton, zooplankton and detritus fields, D2011 used a simple restoring model that diagnosed export production from restoring simulated against observed surface phosphate concentrations. Therefore, the model from D2011 did not account for possible PDO-driven changes in surface nutrient concentrations and instead likely overestimated the variability in export and respiration at depth.

While our modeling framework captures the general patterns of primary and export production reasonably well, it does not include an iron cycle; thus, despite displaying a well-tuned mean state, it may exhibit systematic errors regarding its sensitivity to environmental changes. Furthermore, the model's representation of the respiration processes is relatively pragmatic. In particular, our model lacks an explicit nitrogen cycle including anaerobic remineralization by denitrification under low oxygen conditions (Paulmier et al., 2009). Other limitations include, for instance, a simplistic parameterization of the attenuation of the flux of particulate organic matter which, in our model, neglects any dependence on temperature or oxygen (Laufkötter et al., 2017). Also not considered in the model is the diel vertical migration of zooplankton that actively transports material into the deep ocean (Bianchi et al., 2013). Anthropogenic activities impact the global biogeochemical cycles. In particular, atmospheric deposition of anthropogenic nitrogen and iron may partially relax the iron limitation in the tropical Pacific Ocean (Ito et al., 2016). Industrial fishing may affect the mortality rate of the zooplankton and possibly feed back on productivity and respiration (Getzlaff and Oschlies, 2017). Each of these 'missing' processes may modulate respiration rates and may possibly be correlated with the state of the PDO. An important result of our study is that the PDO-induced changes in respiration are smaller than the PDO-induced changes in oxygen supply by a few percent in most of the eastern tropical Pacific Ocean. We show that this small imbalance integrated over a few decades results in a significant PDO-driven oxygen anomaly that may explain a large part of the observed oxygen decline over the past few decades in this region. Experiments including different biogeochemical parameterizations and processes will need to be performed to better assess the robustness of our results. 
Code and data availability. The Coordinated Ocean-ice Reference Experiments (CORE2) forcing dataset is available at: https://data1. gfdl.noaa.gov/nomads/forms/core/COREv2.html (Large and Yeager, 2009). The code for the Nucleus for European Modeling of the Ocean (NEMO) is available at: https://www.nemo-ocean.eu/ (last access: 27 November 2018). The experiments performed in this study are available at: https://data.geomar.de/thredds/catalog/open_ access/duteil_et_al_2018_bg/catalog.html (Duteil et al., 2018).

Supplement. The supplement related to this article is available online at: https://doi.org/10.5194/bg-15-7111-2018-supplement.

Author contributions. OD designed the study and performed the model experiments. All authors contributed to the analysis and to writing the paper.

Competing interests. The authors declare that they have no conflict of interest.

Acknowledgements. This work is a contribution of the SFB754, supported by the Deutsche Forschungsgemeinschaft. The simulations were performed at the North German Supercomputing Alliance (HLRN).

The article processing charges for this open-access publication were covered by a Research

Centre of the Helmholtz Association.

Edited by: M. Grégoire

Reviewed by: two anonymous referees

\section{References}

Albert, A., Echevin, V., Levy, M., and Aumont, O.: Impact of nearshore wind stress curl on coastal circulation and primary productivity in the Peru upwelling system, J. Geophys. Res., 115, C12033, https://doi.org/10.1029/2010JC006569, 2010.

Belmadani, A., Echevin, V., Codron, F., Takahashi, K., and Junquas, C. What dynamics drive future winds scenarios off Peru and Chile?, Clim. Dyn, 43, 1893-1914, https://doi.org/10.1007/s00382-013-2015-2, 2014.

Bettencourt, J. H., López, C., Hernández-Garcia, E., Montes, I., Sudre, J., Dewitte, B., Paulmier, A., and Garçon, V.: Boundaries of the Peruvian Oxygen Minimum Zone shaped by coherent mesoscale dynamics, Nature Geosci., 8, 937-940, https://doi.org/10.1038/ngeo2570, 2015.

Bopp, L., Resplandy, L., Orr, J. C., Doney, S. C., Dunne, J. P., Gehlen, M., Halloran, P., Heinze, C., Ilyina, T., Séférian, R., Tjiputra, J., and Vichi, M.: Multiple stressors of ocean ecosystems in the 21st century: projections with CMIP5 models, Biogeosciences, 10, 6225-6245, https://doi.org/10.5194/bg-106225-2013, 2013.
Bianchi, D., Galbraith, E. D., Carozza, D. A., Mislan, K. A. S., and Stock, C. A.: Intensification of open-ocean oxygen depletion by vertically migrating animals, Nature Geosci., 6, 545-548, 2013.

Brandt, P., Bange, H. W., Banyte, D., Dengler, M., Didwischus, S.-H., Fischer, T., Greatbatch, R. J., Hahn, J., Kanzow, T., Karstensen, J., Körtzinger, A., Krahmann, G., Schmidtko, S., Stramma, L., Tanhua, T., and Visbeck, M.: On the role of circulation and mixing in the ventilation of oxygen minimum zones with a focus on the eastern tropical North Atlantic, Biogeosciences, 12, 489-512, https://doi.org/10.5194/bg-12-489-2015, 2015.

Cabré, A., Marinov, I., Bernardello, R., and Bianchi, D.: Oxygen minimum zones in the tropical Pacific across CMIP5 models: mean state differences and climate change trends, Biogeosciences, 12, 5429-5454, https://doi.org/10.5194/bg-12-54292015, 2015.

Chenillat, F., Rivière, P., Capet, X., Di Lorenzo, E., and Blanke, B.: North Pacific Gyre Oscillation modulates seasonal timing and ecosystem functioning in the California Current upwelling system, Geophys. Res. Lett., 39, L01606, https://doi.org/10.1029/2011GL049966, 2012.

Cocco, V., Joos, F., Steinacher, M., Frölicher, T. L., Bopp, L., Dunne, J., Gehlen, M., Heinze, C., Orr, J., Oschlies, A., Schneider, B., Segschneider, J., and Tjiputra, J.: Oxygen and indicators of stress for marine life in multi-model global warming projections, Biogeosciences, 10, 1849-1868, https://doi.org/10.5194/bg-10-1849-2013, 2013.

Cravatte, S., Madec, G., Izumo, T., Menkes, C., and Bozec, A.: Progress in the 3-D circulation of the eastern equatorial Pacific in a climate ocean model, Ocean Modell., 17, 28-48, 2007.

Czeschel, R., Stramma, L., and Johnson, G. C.: Oxygen decreases and variability in the eastern equatorial Pacific, J. Geophys. Res., 117, C11019, https://doi.org/10.1029/2012JC008043, 2012.

Deser, M., Alexander, A., and Timlin, M. S.: Evidence for a winddriven intensification of the Kuroshio current extension from the 1970s to the 1980s, J. Climate, 12, 1697-1706, 1999.

Deutsch, C., Brix, H., Ito, T., Frenzel, H., and Thompson, L.: Climate-forced variability of ocean hypoxia, Science, 333, 336339, 2011.

Deutsch, C., Berelson, W. Thunell, R., Weber, T., Tems, C., McManus, J., Crusius, J., Ito, T., Baumgartner, T., Ferreira, V., Mey, J., and van Geen, A.: Centennial changes in North Pacific anoxia linked to tropical trade winds, Science, 345, 665-668, 2014.

Di Lorenzo, E., Schneider, N., Cobb, K. M, Franks, J. S, Chhak, K., Miller, A. J., McWilliams, J. C., Bograd, S. J., Arango, H., Curchitser, E., Powell, T. M., and Rivière, P.: North Pacific Gyre Oscillation links ocean climate and ecosystem change, Geophys. Res. Lett., 35, L08607, https://doi.org/10.1029/2007GL032838, 2008.

Dufresne, J.-L., and 46 coauthors: Climate change projections using the IPSL-CM5 Earth System Model: from CMIP3 to CMIP5, Clim. Dynam., 40, 2123-2165, 2013.

Duteil, O., Böning, C. W., and Oschlies, A.: Variability in subtropical-tropical cells drives oxygen levels in the tropical Pacific Ocean, Geophys. Res. Lett., 41, 8926-8934, https://doi.org/10.1002/2014GL061774, 2014a.

Duteil, O., Schwarzkopf, F. U., Böning, C. W., and Oschlies, A.: Major role of the equatorial current system in setting oxygen levels in the eastern tropical Atlantic Ocean: A high- 
resolution model study, Geophys. Res. Lett., 41, 2033-2040, https://doi.org/10.1002/2013GL058888, 2014b.

Duteil, O., Oschlies, A., and Böning, C. W.: Pacific Decadal Oscillation and recent oxygen decline in the eastern tropical Pacific Ocean, Biogeosciences, in press, available at: https://data.geomar.de/thredds/catalog/open_access/duteil_et_ al_2018_bg/catalog.html, last access: 27 November 2018.

Eddebbar, Y. A., Long, M. C., Resplandy, L., Rödenbeck, C., Rodgers, K. N., Manizza, M., and Keeling, R. F.: Impacts of ENSO on air-sea oxygen exchange: Observations and mechanisms, Global Biogeochem. Cy., 31, 901-921, https://doi.org/10.1002/2017GB005630, 2017.

Garcia, H. E., Locarnini, R. A, Boyer, T. P., Antonov, J. I., Baranova, O. K., Zweng, M. M., and Johnson, D. R.: World Ocean Atlas 2009, Volume 3: Dissolved oxygen, apparent oxygen utilization, and oxygen saturation, Ed. NOAA Atlas NESDIS 70, 344 pp., 2010.

Getzlaff, J. and Dietze, H.: Effects of increased isopycnal diffusivity mimicking the unresolved equatorial intermediate current system in an Earth system climate model, Geophys. Res. Lett., 40, 21662170, https://doi.org/10.1002/grl.50419, 2013.

Getzlaff, J. and Oschlies, A.: Pilot Study on Potential Impacts of Fisheries-Induced Changes in Zooplankton Mortality on Marine Biogeochemistry, Global Biogeochem. Cy., 31, 1656-1673, https://doi.org/10.1002/2017GB005721, 2017.

Getzlaff, J., Dietze, H., and Oschlies, A.: Simulated effects of southern hemispheric wind changes on the Pacific oxygen minimum zone, Geophys. Res. Lett., 43, 728-734, https://doi.org/10.1002/2015GL066841, 2016.

Gnanadesikan, A., Dunne, J. P., and John, J.: Understanding why the volume of suboxic waters does not increase over centuries of global warming in an Earth System Model, Biogeosciences, 9, 1159-1172, https://doi.org/10.5194/bg-9-1159-2012, 2012.

Hong, L., Zhang, L., Chen. L., and Wu, L.: Linkage between the Pacific Decadal Oscillation and the low frequency variability of the Pacific Subtropical Cell, J. Geophys. Res.-Oceans, 119, 34643477, https://doi.org/10.1002/2013JC009650, 2014.

Ito, T. and Deutsch, C.: A conceptual model for the temporal spectrum of oceanic oxygen variability, Geophys. Res. Lett., 37, L03601, https://doi.org/10.1029/2009GL041595, 2010.

Ito, T. and Deutsch, C.: Variability of the oxygen minimum zone in the tropical North Pacific during the late twentieth century, Global Biogeochem. Cy., 27, 1119-1128, https://doi.org/10.1002/2013GB004567, 2013.

Ito T., Nenes, A., Johnson, M., Meskhidze, N., and Deutsch, C.: Acceleration of oxygen decline in the tropical Pacific over the past decades by aerosol pollutants, Nature Geosci., 9, 443447, https://doi.org/10.1038/ngeo2717, 2016.

Ito, T., Minobe, S., Long, M. C., and Deutsch, C.: Upper ocean O2 trends: 1958-2015, Geophys. Res. Lett., 44, 4214-4223, https://doi.org/10.1002/2017GL073613, 2017.

Karnauskas, K. B., Johnson, G. C., and Murtugudde, R.: An equatorial ocean bottleneck in global climate models, J. Clim., 25, 343-349, 2012.

Karstensen, J., Stramma. L., and Visbeck, M.: Oxygen minimum zones in the eastern tropical Atlantic and Pacific Oceans, Prog. Oceanogr., 77, 331-350, https://doi.org/10.1016/j.pocean.2007.05.009, 2008.
Keller, D. P., Kriest, I., Koeve, W., and Oschlies, A.: Southern Ocean biological impacts on global ocean oxygen, Geophys. Res. Lett., 43, 6469-6477, https://doi.org/10.1002/2016GL069630, 2016.

Kriest, I. and Oschlies, A.: MOPS-1.0: towards a model for the regulation of the global oceanic nitrogen budget by marine biogeochemical processes, Geosci. Model Dev., 8, 2929-2957, https://doi.org/10.5194/gmd-8-2929-2015, 2015.

Kriest, I., Khatiwala, S., and Oschlies, A.: Towards an assessment of simple global marine biogeochemical models of different complexity, Prog. Oceanogr., 86, 337-360, https://doi.org/10.1016/j.pocean.2010.05.002, 2010.

Large, W. G. and Yeager, S. G.: The global climatology of an interannually varying air-sea flux data set, Clim. Dyn., 33, 341-364, 2009.

Large, W. G. and Yeager, S. G.: The global climatology of an interannually varying air-sea flux data set, Clim. Dyn., 33, 341-364, https://data1.gfdl.noaa.gov/nomads/forms/ core/COREv2.html (last access: 27 November 2018), 2009.

Laufkötter, C., John, J. G., Stock, C. A., and Dunne, J. P.: Temperature and oxygen dependence of the remineralization of organic matter, Global Biogeochem. Cy., 31, 1038-1050, https://doi.org/10.1002/2017GB005643, 2017.

Lohmann, K. and Latif, M.: Tropical Pacific decadal variability and the subtropical-tropical cells, J. Clim., 18, 5163-5177, 2005.

Long, M. C., Deutsch, C., and Ito, T.: Finding forced trends in oceanic oxygen, Global Biogeochem. Cy., 30, 381-397, https://doi.org/10.1002/2015GB005310, 2016.

Lübbecke, J. F., Böning, C. W., and Biastoch, A.: Variability in the subtropical-tropical cells and its effect on near-surface temperature of the equatorial Pacific: a model study, Ocean Sci., 4, 7388, https://doi.org/10.5194/os-4-73-2008, 2008.

Luo, Y., Liu, Q., and Rothstein, L. M.: Increase of South Pacific eastern subtropical mode water under global warming, Geophys. Res. Lett., 38, L01601, https://doi.org/10.1029/2010GL045878, 2011.

Macias, D., Landry, M. R., Gershunov, A., Miller, A. J., and Franks, P. J. S.: Climatic Control of Upwelling Variability along the Western North-American Coast, PLoS ONE, 7, e30436, https://doi.org/10.1371/journal.pone.0030436, 2012.

Madec, G.: NEMO ocean engine version 3.1. Note Pole Modelisation. 27, Inst. Pierre-Simon Laplace, Paris, 2008.

Mantua, N. J., Hare, S. R., Zhang, Y., Wallace, J. M., and Francis, R. C.: A Pacific interdecadal climate oscillation with impacts on salmon production, B. Am. Meteorol. Soc., 78, 1069-1079, 1997.

Marin, F., Kestenare, E., Delcroix, T., Durand, F., Cravatte, S., Eldin, G., and Bourdalle-Badieu, R.: Annual reversal of the equatorial intermediate current in the Pacific: Observations and model diagnostics, J. Phys. Oceanogr., 40, 915-933, 2010.

Matear, R. J. and Hirst, A. C.: Long-term changes in dissolved oxygen concentrations in the ocean caused by protracted global warming, Global Biogeochem. Cy., 17, 1125, https://doi.org/10.1029/2002GB001997, 2003.

MacDonald, G. M. and Case, R. A.: Variations in the Pacific Decadal Oscillation over the past millennium, Geophys. Res. Lett., 32, L08703, https://doi.org/10.1029/2005GL022478, 2005. 
McCreary, J. P. and Lu, P.: On the interaction between the subtropical and equatorial ocean circulation: The Subtropical Cell, J. Phys. Oceanogr., 24, 466-497, 1994.

McPhaden, M. J. and Zhang, D.: Slowdown of the meridional overturning circulation in the upper Pacific Ocean, Nature, 415, 603608, 2002.

Merrifield, M. A., Thompson, P. R., and Lander, M.: Multidecadal sea level anomalies and trends in the western tropical Pacific, Geophys. Res. Lett., 39, L13602, https://doi.org/10.1029/2012GL052032, 2012.

Messié, M. and Chavez, F.: Global Modes of Sea Surface Temperature Variability in Relation to Regional Climate Indices, J. Climate, 24, 4314-4331, https://doi.org/10.1175/2011JCLI3941.1, 2011.

Miller, A. J., Cayan, D. R., Barnett, T. P., Graham, N. E., and Oberhuber, J. M.: The 1976-77 climate shift of the Pacific Ocean, Oceanography, 7, 21-26, 1994.

Montes, I., Dewitte, B., Gutknecht, E., Paulmier, A., Dadou, I., Oschlies, A., and Garçon, V.: High-resolution modeling of the Eastern Tropical Pacific Oxygen Minimum Zone: Sensitivity to the tropical ocean circulation, J. Geophys. Res.-Oceans, 119, 55155532, https://doi.org/10.1002/2014JC009858, 2014.

Narayan, N., Paul, A., Mulitza, S., and Schulz, M.: Trends in coastal upwelling intensity during the late 20th century, Ocean Sci., 6, 815-823, https://doi.org/10.5194/os-6-815-2010, 2010.

Oschlies, A., Duteil, O., Getzlaff, J., Koeve, W., Landolfi, A., und Schmidtko, S. Patterns of deoxygenation: sensitivity to natural and anthropogenic drivers, Philos. T. Roy. Soc. A, 375, 20160325, https://doi.org/10.1098/rsta.2016.0325, 2017.

Paulmier, A., Kriest, I., and Oschlies, A.: Stoichiometries of remineralisation and denitrification in global biogeochemical ocean models, Biogeosciences, 6, 923-935, https://doi.org/10.5194/bg6-923-2009, 2009.

$\mathrm{Qu}$, T. and Chen, J.: A North Pacific decadal variability in subduction rate, Geophys. Res. Lett., 36, L22602, https://doi.org/10.1029/2009GL040914, 2009.

Ridder, N. N. and England, M. H.: Sensitivity of ocean oxygenation to variations in tropical zonal wind stress magnitude, Global Biogeochem. Cy., 28, 909-926, https://doi.org/10.1002/2013GB004708, 2014.

Schmidtko, S., Stramma, L., und Visbeck, M.: Decline in global oxygen content during the past five decades, Nature, 542, 335339, https://doi.org/10.1038/nature21399, 2017.

Shigemitsu, M., Yamamoto, A., Oka, A., and Yamanaka, Y.: One possible uncertainty in CMIP5 projections of low-oxygen water volume in the Eastern Tropical Pacific, Global Biogeochem. Cy., 31, 804-820, https://doi.org/10.1002/2016GB005447, 2017.
Smith, T. M., Reynolds, R. W., Peterson, T. C., and Lawrimore, J.: Improvements NOAAs Historical Merged Land-Ocean Temp Analysis (1880-2006), J. Climate, 21, 2283-2296, 2008.

Stramma, L., Johnson, G. C., Sprintall, J., and Mohrholz, V.: Expanding oxygen-minimum zones in the tropical oceans, Science, 320, 655-658, 2008.

Stramma, L., Johnson, G. C., Firing, E., and Schmidtko, S: Eastern Pacific oxygen minimum zones: Supply paths and multidecadal changes, J. Geophys. Res.-Oceans, 115, C09011, https://doi.org/10.1029/2009jc005976, 2010.

Stramma, L., Oschlies, A., and Schmidtko, S.: Mismatch between observed and modeled trends in dissolved upper-ocean oxygen over the last $50 \mathrm{yr}$, Biogeosciences, 9, 4045-4057, https://doi.org/10.5194/bg-9-4045-2012, 2012.

Thomas, A. C., Strub, P. T., Waetherbee, R. A., and James, C.: Satellite views of Pacific chlorophyll variability: Comparisons to physical variability, local versus nonlocal influences and links to climate indices, Deep-Sea Res. II, 77, 99-116, https://doi.org/10.1016/j.dsr2.2012.04.008, 2012.

Vergara, O., Dewitte, B., Montes, I., Garçon, V., Ramos, M., Paulmier, A., and Pizarro, O.: Seasonal variability of the oxygen minimum zone off Peru in a high-resolution regional coupled model, Biogeosciences, 13, 4389-4410, https://doi.org/10.5194/bg-134389-2016, 2016.

Yamamoto, A., Abe-Ouchi, A., Shigemitsu, M., Oka, A., Takahashi, K., Ohgaito, R., and Yamanaka, Y.: Global deep ocean oxygenation by enhanced ventilation in the Southern Ocean under longterm global warming, Global Biogeochem. Cy., 29, 1801-1815, https://doi.org/10.1002/2015GB005181, 2015.

Yang, H., Liu, J., Lohmann, G., Shi, X., Hu, Y., and Chen, X.: Ocean-atmosphere dynamics changes associated with prominent ocean surface turbulent heat fluxes trends during 19582013, Ocean Dynam., 66, 353, https://doi.org/10.1007/s10236016-0925-3, 2016.

Zhang, L. and Delworth, T. L.: Analysis of the characteristics and mechanisms of the Pacific decadal oscillation in a suite of coupled models from the Geophysical Fluid Dynamics Laboratory, J. Climate, 28, 7678-7701, https://doi.org/10.1175/JCLI-D-1400647.1, 2015.

Zhang, X. and McPhaden, J.: Eastern Equatorial Pacific Forcing of ENSO Sea Surface Temperature Anomalies, J. Climate, 21, 6070-6079, https://doi.org/10.1175/2008JCLI2422.1, 2008.

Zhou, X., Alves, A., Marsland, S. J., Daohua, B., and Hirst, A. C: Multi-decadal variations of the South Indian Ocean subsurface temperature influenced by Pacific Decadal Oscillation, Tellus A, 69, 1308055, https://doi.org/10.1080/16000870.2017.1308055, 2017. 